\title{
Seafloor fault ruptures along the North Anatolia Fault in the Marmara Sea, Turkey: Link with the adjacent basin turbidite record
}

\author{
Cecilia M.G. McHugh a,b,*, Nicole Braudy a,1, M. Namik Çağatay ${ }^{c}$, Christopher Sorlien ${ }^{\mathrm{d}}$, \\ Marie-Helene Cormier ${ }^{\mathrm{e}, 2}$, Leonardo Seeber ${ }^{\mathrm{b}}$, Pierre Henry ${ }^{\mathrm{f}}$ \\ a School of Earth and Environmental Sciences, Queens College, City University of New York, Flushing, NY 11367, USA \\ ${ }^{\mathrm{b}}$ Lamont-Doherty Earth Observatory of Columbia University, Palisades, NY 10964, USA \\ c ITU EMCOL, Faculty of Mining, Ayazaga, 34469 Istanbul, Turkey \\ d Earth Research Institute, University of California, Santa Barbara, CA 93106, USA \\ e Department of Geological Sciences, University of Missouri, Columbia, MO 65211, USA \\ ${ }^{f}$ CNRS, College de France, CEREGE UMR 7330, 13545 Aix en Provence Cedex 04, France
}

\section{A R T I C L E I N F O}

\section{Article history:}

Received 21 June 2013

Received in revised form 21 February 2014

Accepted 4 March 2014

Available online 11 March 2014

Communicated by D.J.W. Piper

\section{Keywords:}

turbidite

homogenite

earthquake seafloor rupture

Marmara Sea

North Anatolia Fault

\begin{abstract}
A B S T R A C T
The relation between seafloor fault ruptures and the generation of turbidity currents was investigated to better understand the structural growth of tectonic basins with direct implications for earthquake hazard assessment. This study focuses on the Holocene earthquake record of transtensional basins in the Marmara Sea, Turkey, that are associated with the North Anatolian Fault system. The physical and chemical composition of three $10 \mathrm{~m}$-long cores recovered from the Central Basin was studied at high-resolution and turbidite-homogenite units were identified. Turbidite-homogenite units ( $\mathrm{T}-\mathrm{H}$ units) are complex deposits that consist of a sharp basal contact and multiple fining upward beds of sand to coarse silt, above. All are capped by a $25 \mathrm{~cm}$ to $75 \mathrm{~cm}$ thick layer of medium to fine silt. A chronology developed from radiocarbon and short-lived radioisotopes allowed the correlation of these $\mathrm{T}-\mathrm{H}$ units to the historical record of earthquakes that in Turkey goes back 2000 years. We found that the best location to recover the most complete sedimentation record is in the deepest part of a basin or "depocenter" where T-H units constitute $~ 80 \%$ of the sediments. A very good correlation was established between T-H units in Central Basin and proximal inferred historic epicentres along the central Marmara segment of the North Anatolia Fault that occurred in 1343, 860, 740, and 557 AD, and two more distal earthquakes that occurred in 268 and 1963 (or possibly1964). These sedimentation events can then be referred to as "seismo-turbidites".

The results when compared to findings from other transform basins in Marmara Sea reveal a very good correlation between T-H units and historic ruptures. Most importantly, there is a strong correlation between the inferred locations of historical earthquakes and the preservation of turbidite-homogenite units in the basin adjacent to the inferred rupture. The 740 AD earthquake correlates with T-H units in Izmit Gulf and Central Basin and could represent a multi-segment rupture of the NAF. Generally, T-H units appear to be clustered through the Holocene sections, suggesting temporal earthquake clustering in the Marmara Sea region. Such clustering may account for the lack of T-H units and hence large ruptures through the Central Basin since 1343.
\end{abstract}

(c) 2014 Elsevier B.V. All rights reserved.

\section{Introduction}

The link between earthquakes and the generation of mass-wasting and turbidity currents resulting in the deposition of "seismo-turbidites"

\footnotetext{
* Corresponding author at: School of Earth and Environmental Sciences, Queens College, City University of New York, Flushing, NY 11367, USA. Tel.: + 17189973322 fax: +1 7189973299 .

E-mail address: cmchugh@qc.cuny.edu (C.M.G. McHugh).

1 Present address: Department of Geoscience, The University of Wisconsin, Madison, WI 53706, USA

2 Present address: University of Rhode Island, Graduate School of Oceanography, Narragansett, RI 02811, USA
}

has been studied in diverse submarine tectonic settings in recent years to better understand the risk of earthquakes, and tsunamis to coastal populations. Most studies focus on convergent plate boundaries, such as Cascadia offshore western North America (Goldfinger et al., 2003, 2007; Goldfinger, 2011), Galicia, offshore Galicia and Portugal (Gracia et al., 2010; Masson et al., 2011; Bartolome et al., 2012), Kuril trough offshore Japan (Nakajima and Kanai, 2000; Noda et al., 2008), Chile trench offshore Chile (St-Onge et al., 2012), and Hikurangi trench offshore New Zealand (Pouderoux et al., 2012). In contrast to these convergent margin settings, nearshore continental transform boundaries are associated with comparatively smaller but more frequent shallower earthquakes. Because they cross heavily populated regions, earthquakes can be 
disproportionally damaging, primarily not only due to shaking (e.g., liquefaction, land-slides), but also due to ground deformation. Even smalllocalized tsunamis have been associated to strike-slip earthquakes due to dip-slip motions along faults that generated failures and mass wasting (Hornbach et al., 2010; Altinok et al., 2011). Sediments in transform basins preserve unique information about earthquake-triggered sedimentation. These sediments have been studied in the EnriquilloPlantain Garden sinistral transform fault offshore Haiti (McHugh et al., 2011a), the North Anatolia Fault beneath Marmara Sea (McHugh et al., 2006; Sari and Çağatay, 2006; Beck et al., 2007; Çağatay et al., 2012; Drab et al., 2012; Eris et al., 2012), the El Pilar fault in Cariaco Basin, Venezuela (Thunell et al., 1999; Lorenzoni et al., 2012), and the Alpine strike slip fault in New Zealand (e.g., Barnes, 2009). Land paleoseismic studies of the Dead Sea transform have contributed much to the understanding of these transform fault systems by characterizing large and fine scale structures and producing a record of paleoearthquakes (e.g., Marco and Agnon, 1995; Ken-Tor et al., 2001; Migowski et al., 2004). Within the past ten years, much progress has been made in the field of submarine paleoseismology, understanding processes linking submarine earthquakes with sedimentation events and developing techniques for addressing earthquake recurrence intervals and segmentation of fault systems.

What earthquake effects cause sedimentation events? Ground shaking and/or permanent sea-floor deformation such as steepening of slopes? How strong do these effects need to be? These fundamental questions have important practical corollaries: Could a seismoturbidite in a transform basin be triggered by a distal earthquake several segments away from that basin, or alternatively, is it indicative of a proximal seafloor rupture across that same basin? If the latter is generally the case, earthquake-triggered deposits have the potential of identifying the segment of the transform boundary that ruptured and whether the rupture reached the sea floor. Previous investigations of the Cascadia convergent plate boundary have identified fault segments based on the provenance of the turbidites (Goldfinger et al., 2003, 2007; Goldfinger, 2011). In the Hikurangi subduction margin offshore New Zealand, synchronous turbidites were linked to a specific source based on an onland paleoearthquake record, and used to determine earthquake recurrence intervals (Pouderoux et al., 2012). Prior investigations of the North Anatolia Fault dextral transform boundary beneath the Marmara Sea showed that turbidites in three of the main sub-basins were generally deposited adjacent to the fault segment that ruptured (McHugh et al., 2006). A more complex relation between earthquakes and turbidites was found in the well-documented 2010 Mw 7 Haiti earthquake that was associated to the sinistral Enriquillo-PlantainGarden transform boundary (McHugh et al., 2011a, 2011b). Factors such as low sediment supply in the Haiti carbonate margin and a complex earthquake rupture with strike-slip and thrust components may have played a role in the generation of mass-wasting and turbidity currents in this margin where a one-to-one correlation between sedimentation and earthquakes was not found (McHugh et al., 2011b; Taylor et al., 2011). Here we further explore the relation between sea floor fault ruptures and the generation of turbidity currents to better characterize fault segmentation and seismic hazards. Submarine paleoseismology techniques are applied to study three $\sim 10 \mathrm{~m}$-long cores recovered from Central Basin and using multibeam bathymetry and chirp highresolution sub-bottom profiles. Central Basin is one of the main basins in Marmara Sea associated with the North Anatolian Fault system. The results from Central Basin are then compared to findings from other basins in Marmara Sea and from transform basins in other tectonic settings.

The main objectives are to: 1) Investigate if all segment-rupturing earthquakes generate submarine sediment failures and sedimentation events, and if there is a one-to-one correlation between earthquakes and turbidites. 2) Link each event in the sedimentation record to specific earthquake ruptures, determining earthquake recurrence intervals. 3 ) Extend the record of earthquake-generated sedimentation to the early Holocene. The threshold for historical earthquakes considered in this study is magnitude Ms $\geq 6.8$, as assigned by Ambraseys (2002a). Most studies to date have concentrated on the late Holocene within the span of historic earthquakes. A longer earthquake record will contribute to a better understanding of earthquake ruptures along continental transform boundaries in general. But in particular, these results could be critical for geohazards assessment of heavily populated coastal regions such as the Marmara Sea that include the city of Istanbul.

\section{Background}

The North Anatolian Fault (NAF) extends east west for $1600 \mathrm{~km}$ across Turkey and is one of the world's major continental transforms (Fig. 1). The NAF accommodates right-lateral motion between Eurasia and the Anatolia plate. GPS measurements show a relative motion of 23-25 mm/yr (Straub et al., 1997; McClusky et al., 2000; Reilinger et al., 2010). The Marmara Sea is a transtensional trough spatially and genetically associated with the northern branch of the NAF (NAF-N; Fig. 1). The Marmara Sea is subdivided into subsiding Plio-Pleistocene basins that are as deep as $1200 \mathrm{~m}$ and separated by ridges $550 \mathrm{~m}$ deep (Rangin et al., 2001). From west to east the main basins are Tekirdag, Central, Kumburgaz, Cinarcik, and Izmit Gulf (Fig. 1).

The 1912 Mw 7.4 Ganos earthquake ruptured the NAF-N on land (Rockwell et al., 2001, 2009; Ambraseys, 2002a; Altunel et al., 2004; Aksoy et al, 2010; Meghraoui et al., 2012). Armijo et al. (2005) proposed that the 1912 rupture extended for $~ 140 \mathrm{~km}$ from the Gulf of Saros, ending in the Central Basin step-over in Marmara Sea (Fig. 1). East of Marmara Sea, the NAF ruptured in a sequence of seven Ms $>7$ earthquakes progressively from east to west, starting in 1939 (Toksöz et al., 1979; Barka and Kadinsky-Cade, 1988; Barka, 1999; Toksöz et al., 1999). The latest and westernmost events, the $1999 \mathrm{Mw} 7.4$ Izmit and the Mw 7.2 Duzce earthquakes, were destructive ( 17,000 deaths). The Marmara segment of the NAF is the only remaining unruptured seismic gap (Ambraseys, 2002a) and has accumulated as much elastic strain as released in the 1999 sequence (Hubert-Ferrari et al., 2000; Parsons et al., 2000; Reilinger et al., 2000). To the east of Marmara Sea, it has also been proposed that the 1999 seafloor rupture extended for $\sim 80 \mathrm{~km}$ into Marmara Sea (Aksoy et al., 2010; Gasperini et al, 2011; Uçarkus et al., 2011). Other studies are more conservative in their estimates of the length of the 1999 seafloor ruptures into Izmit Gulf. Cormier et al. (2006) proposed that while the aftershock distribution and geodetic data indicate that the subsurface rupture extended $50 \mathrm{~km}$ into Marmara Sea, direct evidence is lacking for any seafloor rupture extending beyond $25 \mathrm{~km}$ west of Izmit. The extent of both the 1912 and 1999 seafloor ruptures has implications for understanding and modelling seismic risk for the segment of the NAF that presumably remains locked under Marmara Sea. It is therefore critical to provide as much geological information on historic and pre-historic ruptures as possible.

\section{Submarine paleoseismology prior results}

The Marmara Sea basins are excellent for submarine paleoseismology studies because they are closed basins that have preserved turbidites in their deepest part (Fig. 1). Structurally, the progressive tilting in some of the basin floors towards the fault has preserved thick turbidite deposits in the basins deepest part or "depocenters" (Fig. 2; Cormier et al., 2006; Seeber et al., 2006; Kurt et al., 2013). Coring in these depocenters has allowed the recovery of a record of turbidites that have been dated effectively (McHugh et al., 2006; Çağatay et al., 2012). Most importantly, these T-Hs were linked to a historic record of earthquakes that goes back 2000 years (Ambraseys and Finkel, 1995; Ambraseys and Jackson, 2000; Ambraseys, 2002a). Additionally, a very thick homogenite $(\sim 2 \mathrm{~m})$ was dated at 14.6 cal ka BP in Central Basin (Beck et al., 2007), and based on geochemical elemental composition correlations were made of earthquake-triggered turbidites across basins (Drab et al., 2012). Other 


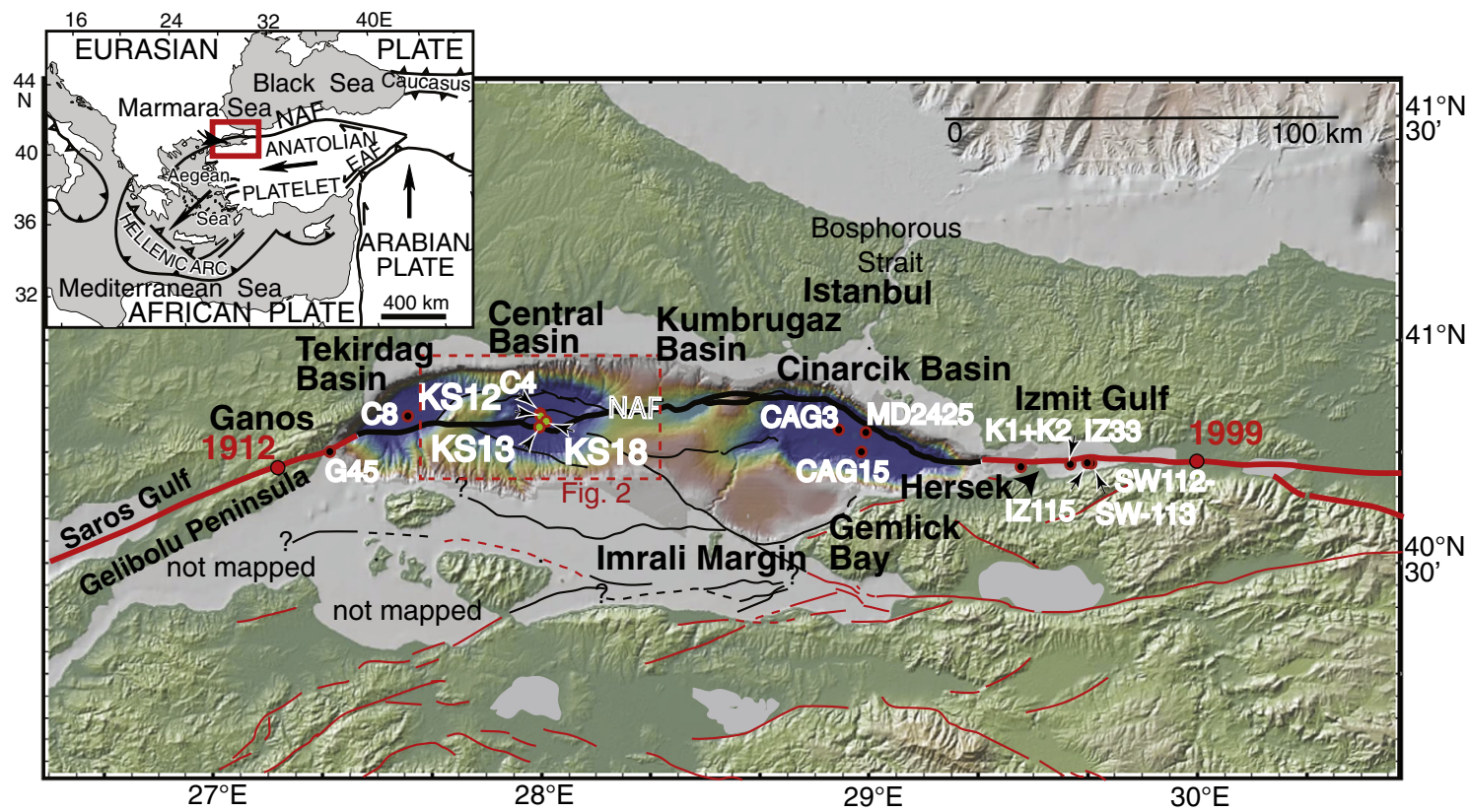

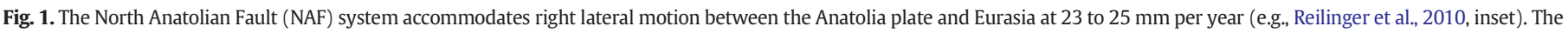

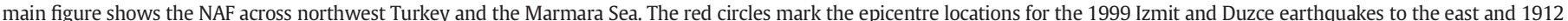

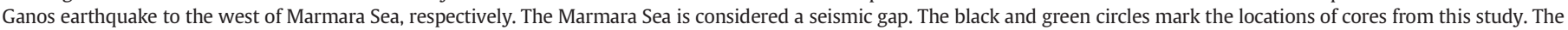

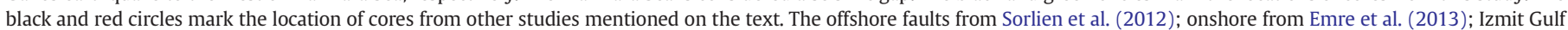
from Cormier et al. (2006); the Gemlik Bay faults were simplified from Gasperini et al. (2011) and Kuscu et al. (2009).

studies focused in extracting the earthquake induced sedimentation record from Cinarcik Basin (Sari and Çağatay, 2006; Eris et al., 2012).

Lithologically, the turbidite-homogenite units consist of a sharp basal contact below multiple fining-upward beds of sand to coarse silt. This relatively thin and finely stratified basal deposit leads upward into an $\sim 50$ to $100-\mathrm{cm}$ thick, homogeneous medium- to fine-silt unit (e.g., Çağatay et al., 2012; McHugh et al., 2006). Several fining upward sequences indicate multiple episodes of traction and deposition within the initial stage of what is interpreted as one deposition event. This stratigraphy suggests secondary processes such as earthquakes that rupture through a basin triggering multiple slope failures and turbidites, and/or long wave, seiche-like currents (McHugh et al., 2011a). Both such processes will lead to turbidites interfering with each other and are likely in the close-contour shape of the basins in the Marmara Sea.

\section{Methods}

Three $10 \mathrm{~m}$ long cores were recovered during the MarNaut Expedition to Marmara Sea from the R/V L' Atalante (Géli et al., 2008) and sampled every $2 \mathrm{~cm}$ to $5 \mathrm{~cm}$ apart. Cores KS13, 18 and 12 were recovered from the deepest part of Central Basin at $\sim 1260 \mathrm{~m}$ (Fig. 2). The Central Basin lithologic data was enhanced by high-resolution multibeam bathymetry, side-scan sonar, sub-bottom profiles (CHIRP) and a large collection of gravity and piston cores obtained during previous surveys (e.g., Rangin et al., 2001; Armijo et al., 2002, 2005; Beck et al., 2007). The cores were described and photographed according to the Integrated Ocean Drilling Program guidelines for lithostratigraphy (Expedition 317 Scientists, 2011). The sediments were studied by applying a multiproxy approach to identify the turbidite-homogenite units that consisted of grain size variability, geochemical elemental composition and physical properties. The grain size variability was determined at 2 and $5 \mathrm{~cm}$ spacing intervals by using a Sedigraph 5100 at Queens College, City University of New York. The values obtained were converted to grain size percentages based on the sample weight calculations. The cores were scanned with the ITRAX Core scanner at Istanbul Technical University
Eastern Mediterranean Centre for Oceanography and Limnology “(EMCOL) Core Analysis” Laboratory of Dr. Namik Çağatay. The sediments' elemental composition was measured with X-ray fluorescence at $1 \mathrm{~mm}$ intervals. The elemental analysis signal for KS12 is discontinuous below $300 \mathrm{~cm}$ (not good data). All other cores have good data. The physical properties (bulk density, magnetic susceptibility, p wave velocity) of the sediment were measured on split cores with the MSCL core logger at the ITU-EMCOL facility also at $1 \mathrm{~mm}$ intervals. The sediment analyses were better for understanding the stratigraphy than the X-ray imagery obtained from the core scanner, and therefore the $\mathrm{X}$-ray images were not used.

A chronology was established from ${ }^{14} \mathrm{C}$ derived from foraminifera (Table 1), and from short-lived radioisotopes $\left({ }^{137} \mathrm{Cs}\right.$ and $\left.{ }^{210} \mathrm{~Pb}\right)$. Radiocarbon dating was conducted at the National Ocean Sciences Accelerator Mass Spectrometry Facility at Woods Hole, MA, USA. The ages were calibrated to calendar years using the program CALIB 6.0 and are shown as 1 and 2 sigma values (Stuvier et al, 2005; Table 1). The radiocarbon reservoir corrections applied used a weighted mean of $81 \Delta R$ with a standard deviation (square root of variance) of 14 , and an average uncertainty of 28 , calibrated from samples studied by Siani et al. (2000). Gamma counting for short-lived radioisotopes was conducted at Rensselaer Polytechnic University at the laboratory of Dr. Richard Bopp. The ${ }^{137}$ Cs chronologies reveal both the 1986 Chernobyl release peak and the 1965 nuclear testing global fall-out (Buesseler et al., 1987; Crusius, 1992; Eremeev et al., 1995; Stanev et al., 1995; Appleby, 2000). The decay of excess ${ }^{210} \mathrm{~Pb}$ was used to date sediments from 1850 to the present.

\section{Results}

The sedimentation history from cores KS13, 18 and 12 was used to identify turbidite-homogenite units (T-H units) by detailed analyses of the lithology, grain size, sedimentary structures and physical properties (Figs. 3, 4A, B, C; 5A). The sediment was analysed for its chemical composition and linked to a chronology derived from short-lived 
A

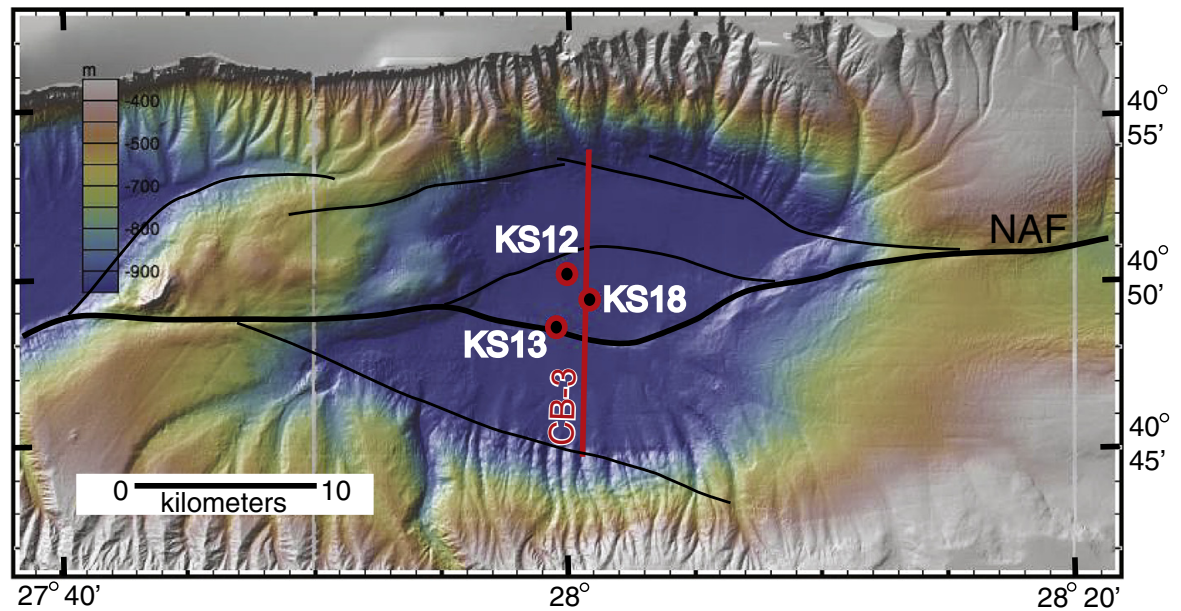

B

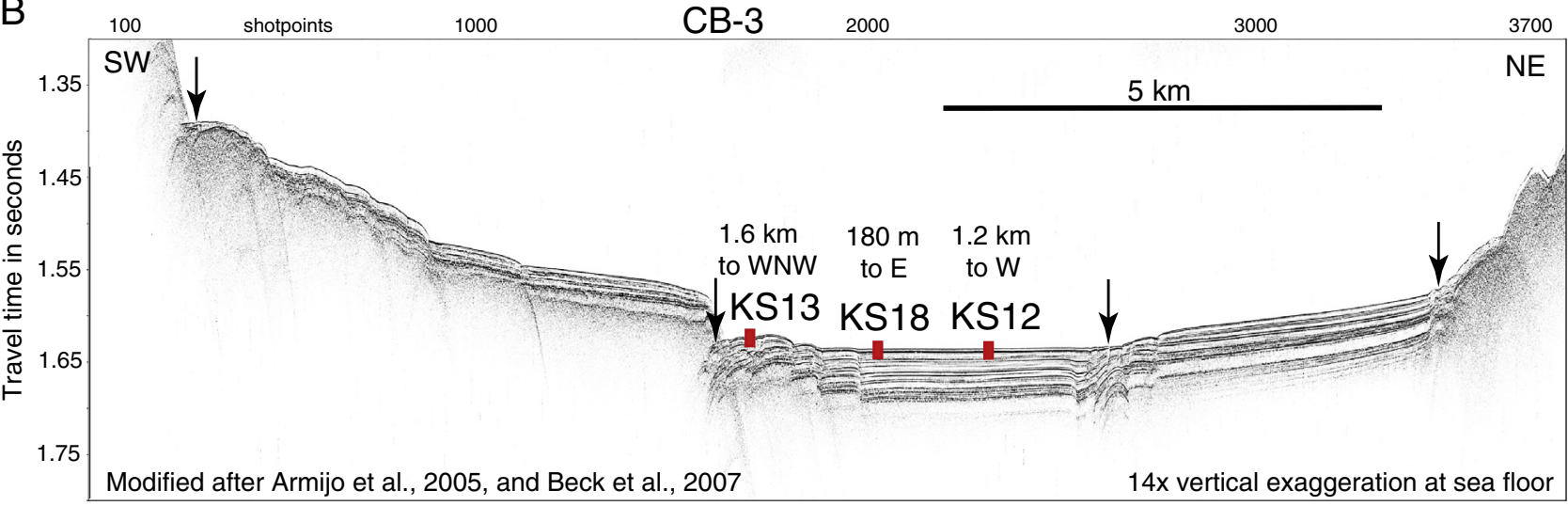

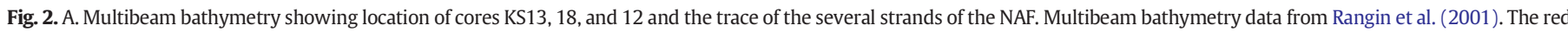

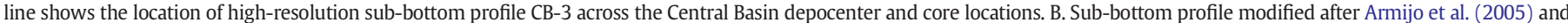

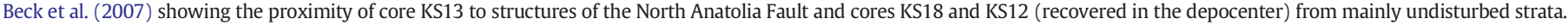

radioisotopes and radiocarbon (Figs. 5B, 6). The data was then interpreted within the context of the multibeam bathymetry and chirp sub-bottom profiles.

\subsection{Lithology}

The lithology of the deep basin cores is rather simple with all three cores composed mainly of clayey silt interbedded with sand and silt laminae ( $<1 \mathrm{~cm}$ thick); Fig. 4A, B, C. Silt lenses are scattered throughout the sediment in the three cores. Mottling (black and beige, circular to elongated in shape and sometimes with diffuse borders) is also common.

\subsubsection{Grain size}

Based on the weight of each sample, the weight percent for each grain size fraction was determined as sand, coarse silt, medium silt, medium fine silt, fine silt, and clay (Fig. 5A). The detail in grain sizes was needed to document the coarser grain part of the deposit (turbidite) and the base and top of the homogenite part of the deposit described in Section 5.1.2. The median and average for each grain size fraction, expressed as weight percent, allowed comparison of the grain size variability for cores KS13, KS18 and KS12. The sand content in each core varies slightly depending on the core location. Core KS13, the closest to the slope canyon drainage systems and NAF scarps in Central Basin, contains the greatest sand content with a mean averaged value of
4.2\%. In core KS18 and KS 12, mean values for total sand content are $2.4 \%$ and $2.5 \%$, respectively (Table 2 ).

\subsubsection{Sedimentary structures}

Turbidite-homogenite $(\mathrm{T}-\mathrm{H})$ units and turbidites $(\mathrm{T})$ constitute $\sim 80 \%$ of the sediment. Generally, the basal part of the T-H units is laminated, $\sim 5 \mathrm{~cm}$ thick and rich in sand and coarse silt. It has an overall fining upward trend (Figs. 3, 4, 5). The sedimentary structures within the basal coarser-grained unit include wavy laminae, clay clasts and cross-bedding. The top part of the T-H unit is homogeneous, ranges from $\sim 10$ to $75 \mathrm{~cm}$ in thickness and is composed of mediumfine- and fine-silt (Figs. 3, 4, 5). Both the basal turbidite and homogenite parts of the T-H units fine upward (Fig. 3). The hemipelagic deposits in between the $\mathrm{T}-\mathrm{H}$ units are composed of clay and very fine silt and contain well-preserved foraminifers used for radiocarbon dating. It was consistently documented in all studied cores that the homogenite part of the $\mathrm{T}-\mathrm{H}$ units rarely contains foraminifers. Bioturbation was observed near the top of the homogenite part of the $\mathrm{T}-\mathrm{H}$ unit and to a lesser extent within the hemipelagic interval. This is common in Marmara Sea as well as in other studied settings (e.g., McHugh et al., 2011a).

The difference between turbidites and $\mathrm{T}-\mathrm{H}$ units is that turbidites are composed of a single normally graded bed (if $\geq 1 \mathrm{~cm}$-thick) or laminae (if $<1 \mathrm{~cm}$ thick) of sand or coarse silt, and do not contain the homogeneous mud above (Fig. 4). In contrast, turbidite-homogenite (T-H) 
Table 1

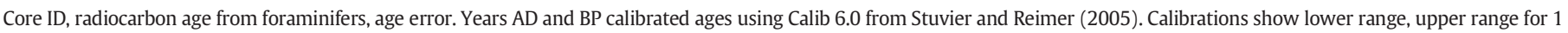
sigma and 2 sigma, and the median probability ages.

\begin{tabular}{|c|c|c|c|c|c|c|c|c|c|c|}
\hline \multirow[t]{2}{*}{ Core ID } & \multirow[t]{2}{*}{${ }^{14} \mathrm{C}$ age } & \multirow[t]{2}{*}{ Age error } & \multicolumn{4}{|c|}{ Calibrated ages $\mathrm{AD} / \mathrm{BC}$} & \multicolumn{4}{|c|}{ Calibrated ages BP } \\
\hline & & & & Lower range & Upper range & Median probability & & Lower range & Upper range & Median probability \\
\hline \multirow[t]{2}{*}{ KS12-2-122 } & 1570 & 44.8 & $1 \sigma$ & 861 & 982 & 913 & $1 \sigma$ & 968 & 1089 & 1037 \\
\hline & & & $2 \sigma$ & 798 & 1019 & 913 & $2 \sigma$ & 931 & 1152 & 1037 \\
\hline \multirow[t]{2}{*}{ KS12-3-198 } & 2160 & 41 & $1 \sigma$ & 241 & 361 & 297 & $1 \sigma$ & 1589 & 1709 & 1653 \\
\hline & & & $2 \sigma$ & 176 & 414 & 297 & $2 \sigma$ & 1536 & 1774 & 1653 \\
\hline \multirow[t]{2}{*}{ KS12-5-478 } & 3570 & 53 & $1 \sigma$ & -1489 & -1368 & -1425 & $1 \sigma$ & 3317 & 3438 & 3374 \\
\hline & & & $2 \sigma$ & -1561 & -1287 & -1425 & $2 \sigma$ & 3236 & 3510 & 3374 \\
\hline \multirow[t]{2}{*}{ KS12-6-495 } & 3140 & 37.5 & $1 \sigma$ & -915 & -817 & -875 & $1 \sigma$ & 2766 & 2864 & 2824 \\
\hline & & & $2 \sigma$ & -978 & -791 & -875 & $2 \sigma$ & 2740 & 2927 & 2824 \\
\hline \multirow[t]{2}{*}{ KS12-6-570 } & 3750 & 61.7 & $1 \sigma$ & -1707 & -1538 & -1629 & $1 \sigma$ & 3487 & 3656 & 3578 \\
\hline & & & $2 \sigma$ & -1804 & -1463 & -1629 & $2 \sigma$ & 3412 & 3753 & 3578 \\
\hline \multirow[t]{2}{*}{ KS12-7-642 } & 3740 & 48.8 & $1 \sigma$ & -1679 & -1540 & -1615 & $1 \sigma$ & 3489 & 3628 & 3564 \\
\hline & & & $2 \sigma$ & -1747 & -1482 & -1615 & $2 \sigma$ & 3431 & 3696 & 3564 \\
\hline \multirow[t]{2}{*}{ KS13-2-123 } & 1980 & 34.4 & $1 \sigma$ & 455 & 554 & 506 & $1 \sigma$ & 1396 & 1495 & 1444 \\
\hline & & & $2 \sigma$ & 419 & 602 & 506 & $2 \sigma$ & 1348 & 1531 & 1444 \\
\hline \multirow[t]{2}{*}{ KS13-4-317 } & 3500 & 57.3 & $1 \sigma$ & -1413 & -1276 & -1344 & $1 \sigma$ & 3225 & 3362 & 3293 \\
\hline & & & $2 \sigma$ & -1484 & -1193 & -1344 & $2 \sigma$ & 3142 & 3433 & 3293 \\
\hline \multirow[t]{2}{*}{ KS13-4-355 } & 3800 & 37.5 & $1 \sigma$ & -1740 & -1629 & -1691 & $1 \sigma$ & 3578 & 3689 & 3640 \\
\hline & & & $2 \sigma$ & -1830 & -1576 & -1691 & $2 \sigma$ & 3525 & 3779 & 3640 \\
\hline \multirow[t]{2}{*}{ KS13-6-497 } & 4770 & 37.5 & $1 \sigma$ & -3005 & -2900 & -2962 & $1 \sigma$ & 4849 & 4954 & 4911 \\
\hline & & & $2 \sigma$ & -3074 & -2876 & -2962 & $2 \sigma$ & 4825 & 5023 & 4911 \\
\hline \multirow[t]{2}{*}{ KS13-9-840 } & 5350 & 57.3 & $1 \sigma$ & -3740 & -3626 & -3683 & $1 \sigma$ & 5575 & 5689 & 5632 \\
\hline & & & $2 \sigma$ & -3812 & -3532 & -3683 & $2 \sigma$ & 5481 & 5761 & 5632 \\
\hline \multirow[t]{2}{*}{ KS18-2-124 } & 1710 & 44.8 & $1 \sigma$ & 699 & 800 & 757 & $1 \sigma$ & 1150 & 1251 & 1193 \\
\hline & & & $2 \sigma$ & 672 & 873 & 757 & $2 \sigma$ & 1077 & 1278 & 1193 \\
\hline \multirow[t]{2}{*}{ KS18-3-192 } & 1880 & 41 & $1 \sigma$ & 574 & 658 & 610 & $1 \sigma$ & 1292 & 1376 & 1340 \\
\hline & & & $2 \sigma$ & 504 & 690 & 610 & $2 \sigma$ & 1260 & 1446 & 1340 \\
\hline \multirow[t]{2}{*}{ KS18-3-192 } & 2170 & 57.3 & $1 \sigma$ & 210 & 368 & 284 & $1 \sigma$ & 1582 & 1740 & 1666 \\
\hline & & & $2 \sigma$ & 138 & 426 & 284 & $2 \sigma$ & 1524 & 1812 & 1666 \\
\hline \multirow[t]{2}{*}{ KS18-5-392 } & 3090 & 53 & $1 \sigma$ & -884 & -781 & -835 & $1 \sigma$ & 2730 & 2833 & 2784 \\
\hline & & & $2 \sigma$ & -963 & -744 & -835 & $2 \sigma$ & 2693 & 2912 & 2784 \\
\hline \multirow[t]{2}{*}{ KS18-5-460 } & 3630 & 53 & $1 \sigma$ & -1549 & -1417 & -1489 & $1 \sigma$ & 3366 & 3498 & 3438 \\
\hline & & & $2 \sigma$ & -1626 & -1371 & -1489 & $2 \sigma$ & 3320 & 3575 & 3438 \\
\hline \multirow[t]{2}{*}{ KS18-6-500 } & 3780 & 44.8 & $1 \sigma$ & -1730 & -1604 & -1666 & $1 \sigma$ & 3553 & 3679 & 3615 \\
\hline & & & $2 \sigma$ & -1803 & -1523 & -1666 & $2 \sigma$ & 3472 & 3752 & 3615 \\
\hline \multirow[t]{2}{*}{ KS18-7-605 } & 3860 & 41 & $1 \sigma$ & -1848 & -1716 & -1772 & $1 \sigma$ & 3665 & 3797 & 3721 \\
\hline & & & $2 \sigma$ & -1890 & -1648 & -1772 & $2 \sigma$ & 3597 & 3839 & 3721 \\
\hline \multirow[t]{2}{*}{ KS18-9-780 } & 4670 & 61.7 & $1 \sigma$ & -2922 & -2753 & -2854 & $1 \sigma$ & 4702 & 4871 & 4803 \\
\hline & & & $2 \sigma$ & -3015 & -2656 & -2854 & $2 \sigma$ & 4605 & 4964 & 4803 \\
\hline
\end{tabular}

Calibrated $\mathrm{BC}$ ranges noted as negative numbers.

units are much thicker and complex sedimentary deposits containing several basal sand or coarse silt laminae and a thick homogeneous fine grained deposit above (Figs. 3A, B, C, 4).

\subsubsection{Physical properties}

In the Marmara Sea and other marine settings (e. g., Expedition 317 Scientists, 2011) bulk density and magnetic susceptibility were commonly correlated with sand and coarse silt. But magnetic susceptibility is also an indication of the magnetic character of the sediment that can be influenced by other variables than grain size. There is a substantial drop of the magnetic susceptibility signal below $300 \mathrm{~cm}$ in KS12, 250 $\mathrm{cm}$ in KS13, and $320 \mathrm{~cm}$ in KS18 (e.g., Fig. 5A). The most likely cause for the drop in magnetic susceptibility below $3 \mathrm{~m}$ was related to iron oxide reduction and pyrite precipitation in relation to the sulphate methane reaction zone (Çağatay et al., 2012; Drab et al., 2012). The long-term changes in the magnetic susceptibility signal (above and below $3 \mathrm{~m}$ ) do not preclude the correlation between slight increases in magnetic susceptibility and the sandy part of the $\mathrm{T}-\mathrm{H}$ units, for example, in KS12, T-H 2 at $124 \mathrm{~cm}$ (Fig. 5A).

\subsection{Elemental geochemistry}

The elemental composition of the cores KS13, 18 and 12 generally shows little variability, but some trends are visible (Fig. 5B). The basal sand or coarse silt can be associated with $\mathrm{Ca}$ and $\mathrm{Sr}$ enrichment indicative of the entrainment of shell material during sediment transport (Fig. 3C). This pattern was observed in earthquake-generated turbidites in the Ionian Sea (Hakimian, 2012), Canal du Sud in Haiti (McHugh et al., 2011a), and Izmit Gulf, Turkey (Çağatay et al., 2012). Shells transported from shallower water depths and rapid burial allow for the preservation of marine microfossils. Generally $\mathrm{Al}$ and $\mathrm{Si}$ follow very similar patterns and are more abundant in the sand and coarse silt intervals. Silica is always more abundant than Al. The homogenite part of the deposit, composed of medium and medium-fine silt, shows some enrichment in $\mathrm{Al}$ and $\mathrm{Si}$, and in some cases with Fe. Generally $\mathrm{K}$ and Ti tend to be concentrated in the medium fine silt fraction. Medium silt shows enrichment in sulphur (Fig. 3C), and this may be the result of the accumulation of organic matter under the low oxygen conditions. It is possible that the events that deposited the black silt-rich laminae transported the organic matter with the coarser grained sediment. The sediment beneath the base of the $\mathrm{T}-\mathrm{H}$ units is commonly enriched in Mn in the Marmara Sea cores (Fig. 3C). Higher concentrations of Mn below the base of $\mathrm{T}-\mathrm{H}$ units were also reported offshore Haiti after the 2010 earthquake (McHugh et al., 2011a). These higher concentrations of Mn can be explained as a diagenetic enrichment at the oxic/anoxic interface of the sediments in a basin where the bottom waters are oxic (Çağatay et al., 2012). Sediment transport and reworking during gravity flows that stirred the bottom sediments lead to the dissolution of $\mathrm{Mn}$, its diffusion upward, and its concentration below the $\mathrm{T}-\mathrm{H}$ units. 


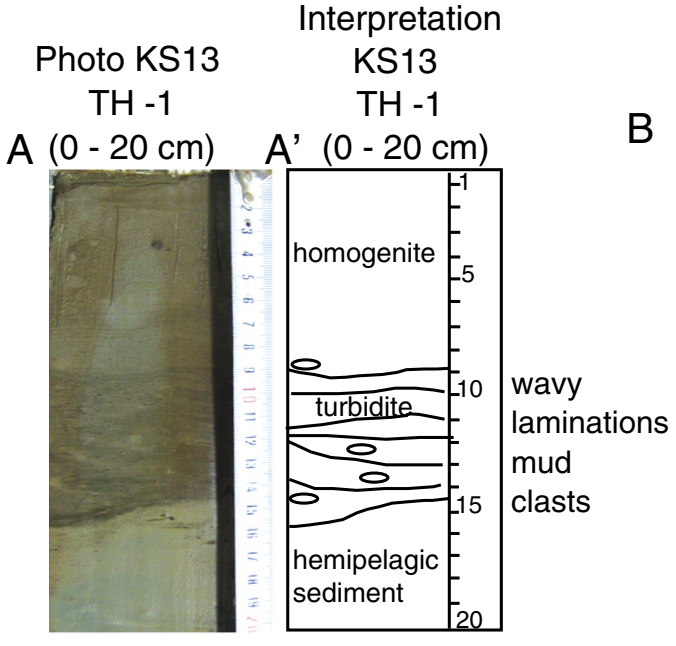
Photo KS12
$\mathrm{TH}-2$

B $(45-125 \mathrm{~cm})$

A $(0-20 \mathrm{~cm})$

$(45-125 \mathrm{~cm})$

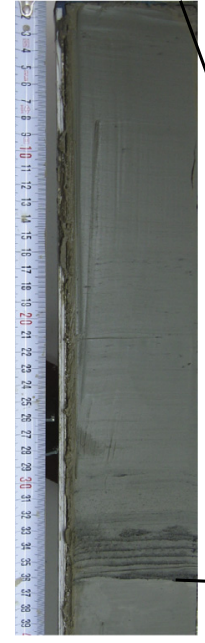

B' Grain size KS12- TH - $2(45-125 \mathrm{~cm})$

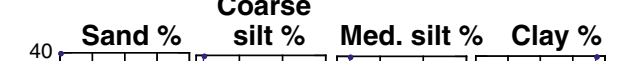

Photo KS13
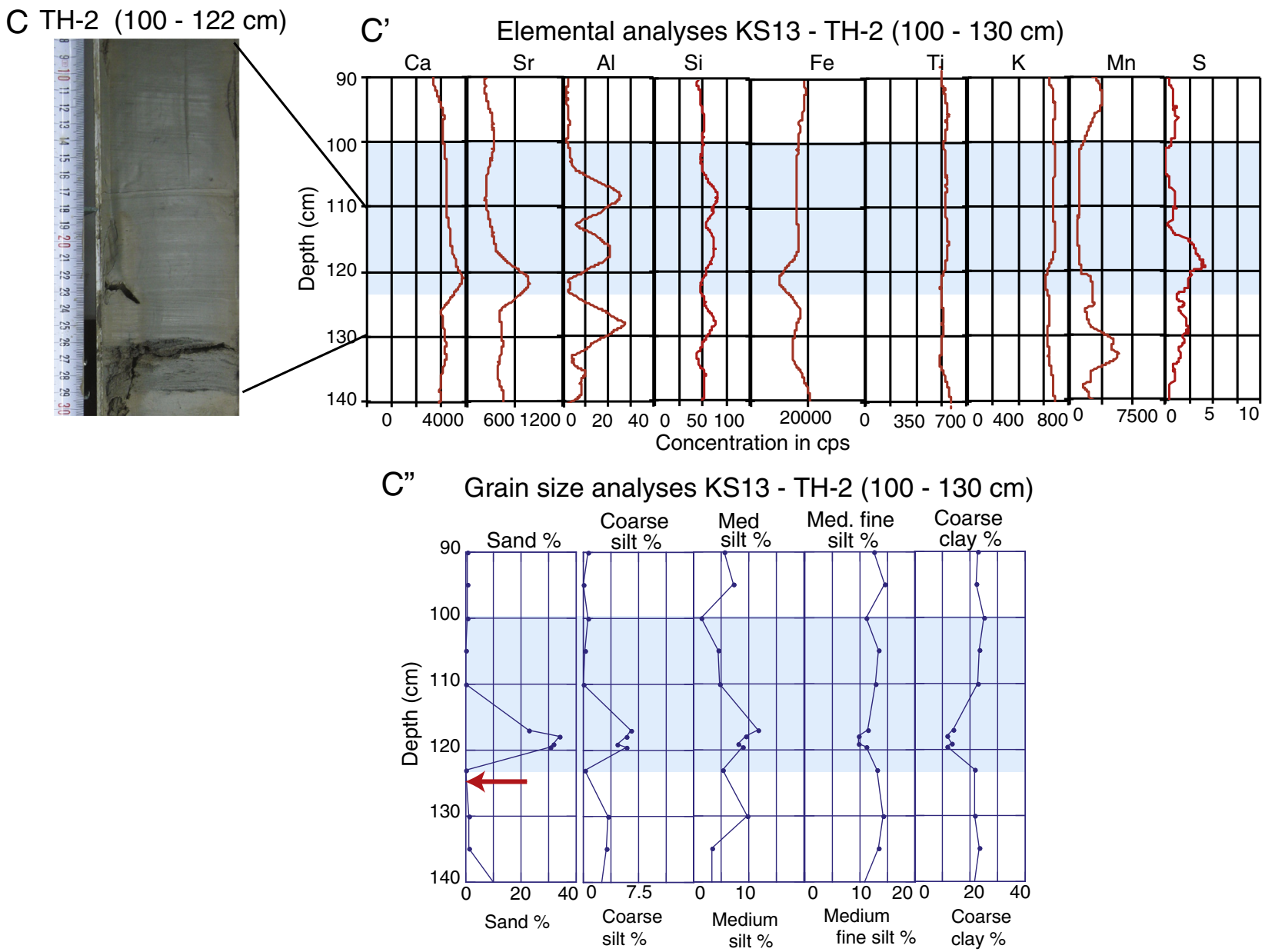

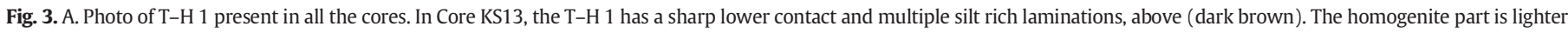

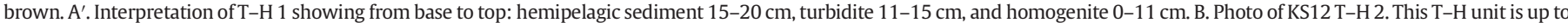

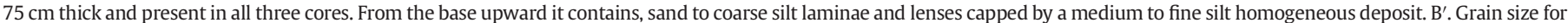

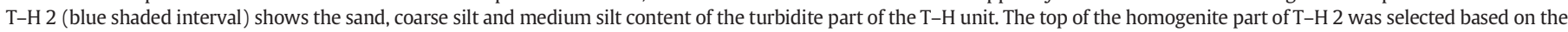

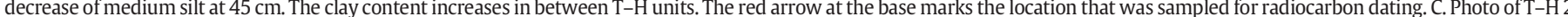

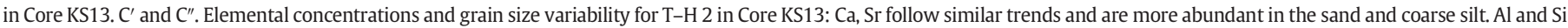

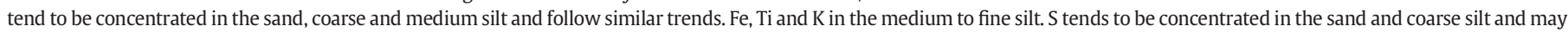

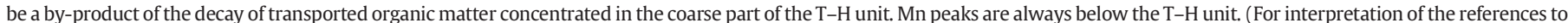
colour in this figure legend, the reader is referred to the web version of this article.) 


\section{3. $\mathrm{T}-\mathrm{H}$ units of Central Basin}

The multiproxy approach permitted the identification of twenty T-H units in Cores KS12 and KS13, twenty-one in Core KS 18 (Figs. 4, 5). A few other turbidites are present in the cores but have not been included as potentially earthquake-triggered since they do not fit the characteristics of multiple bedding and thick deposits above. These gravitational flows could have been caused by processes other than earthquakes like slope instabilities.

\subsubsection{Core KS13}

Core KS13 has the most sand content of all the cores with a mean of 4.18\%. The T-Hs 2-17, T-Hs $19-20$ and T 1-4 are sand rich (Table 2, Fig. 4A). The T-Hs 1 and 18 are dominated by coarse, medium and medium fine silt. Some T-H units for example, T-H 2 are $40 \mathrm{~cm}$ in thickness. The proximity to the base of the slope and the NSF fault scarps explains the greater sand content. Elemental concentrations follow those described above.

\subsubsection{Core KS18}

Grain size (Table 2) showed that this core has less sand than Core KS-13 (mean content $2.48 \%$ versus $4.18 \%$ in Core KS13). Four T-H units $(1,7,13,21)$ ranging in thickness from 30 to $50 \mathrm{~cm}$ do not contain sand and are rich in coarse and medium silt (Fig. 4B). Only one sand turbidite is present in this core (T1). The results of the elemental analysis and physical properties are very similar in this core to those obtained for core KS12 (see below).

\subsubsection{Core KS12}

This core contains less sand (mean sand content 2.48\%) than Core KS-13 (mean sand content $4.18 \%$ ) possibly due to its distance $(\sim 3 \mathrm{~km})$ from the largest scarp associated with the several strands of the NAF fault, and the base of the slope (Fig. 2; Table 2). Six of the $20 \mathrm{~T}-\mathrm{H}$ units are rich in silt (Fig. 4C). The four turbidites present are rich in silt (T1, 2, 3, 4; Fig. 4C). The elemental concentrations are similar to those previously described (Figs. 3, 5A, B). The bulk density ranges between 1.4 and $1.8 \mathrm{~g} / \mathrm{cc}$ and generally peaks with sand in K12, K13 and K18 cores. The magnetic susceptibility for K12, K13 and K18 increases and
A

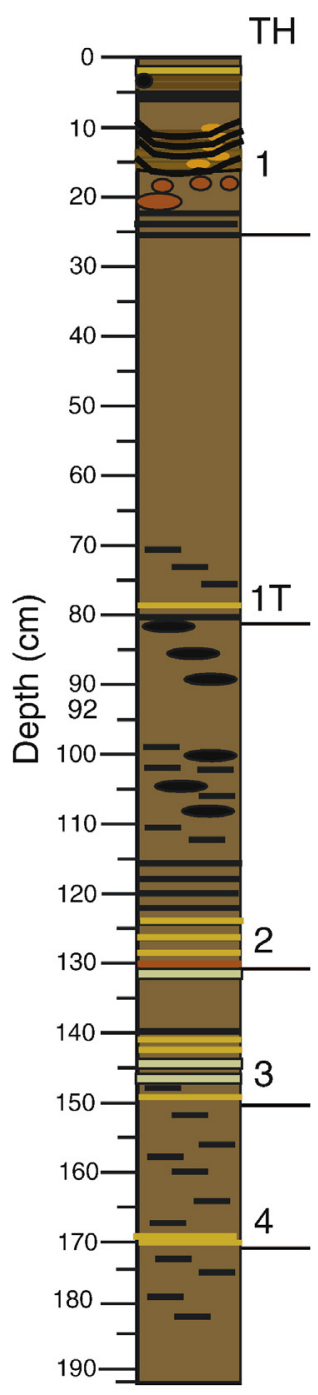

$\mathrm{TH}$

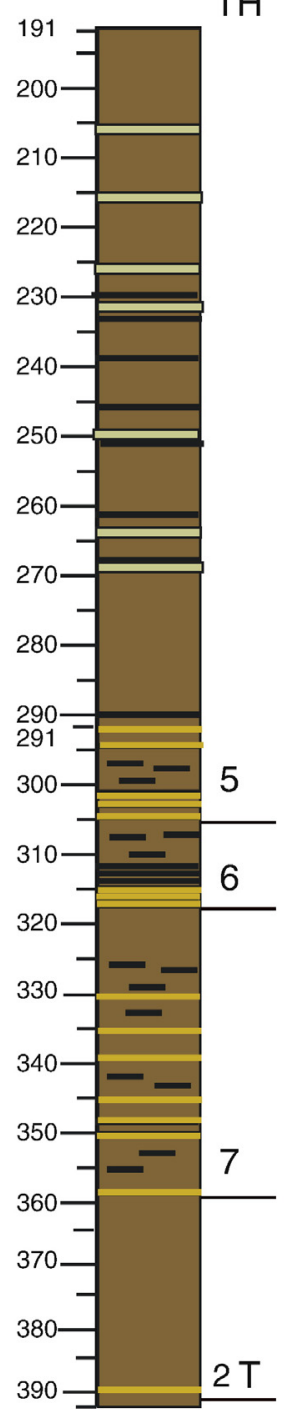

Core KS-13

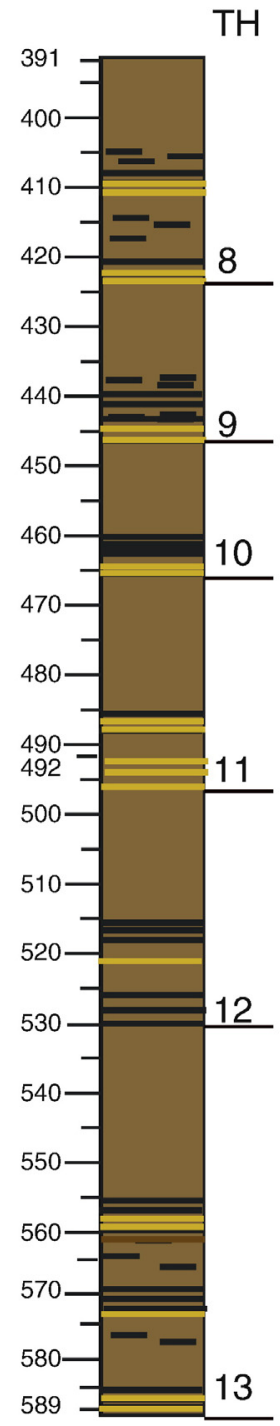

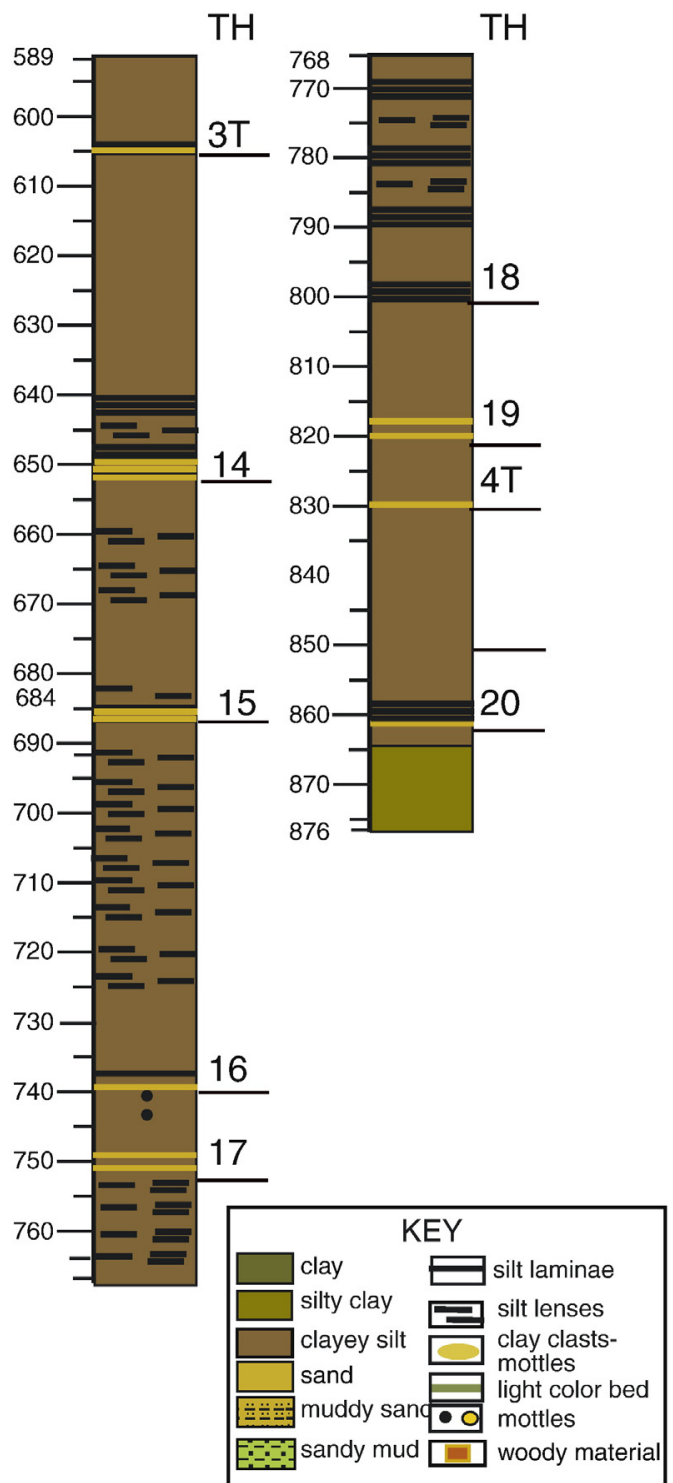


B

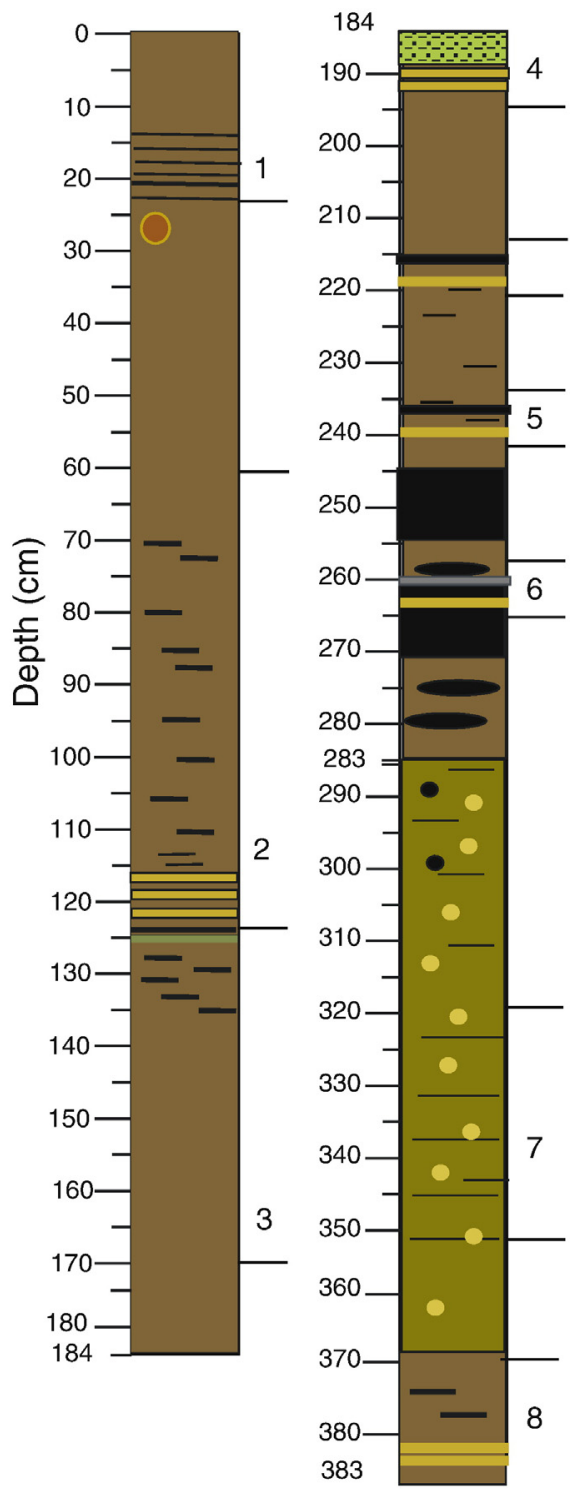

Core KS-18

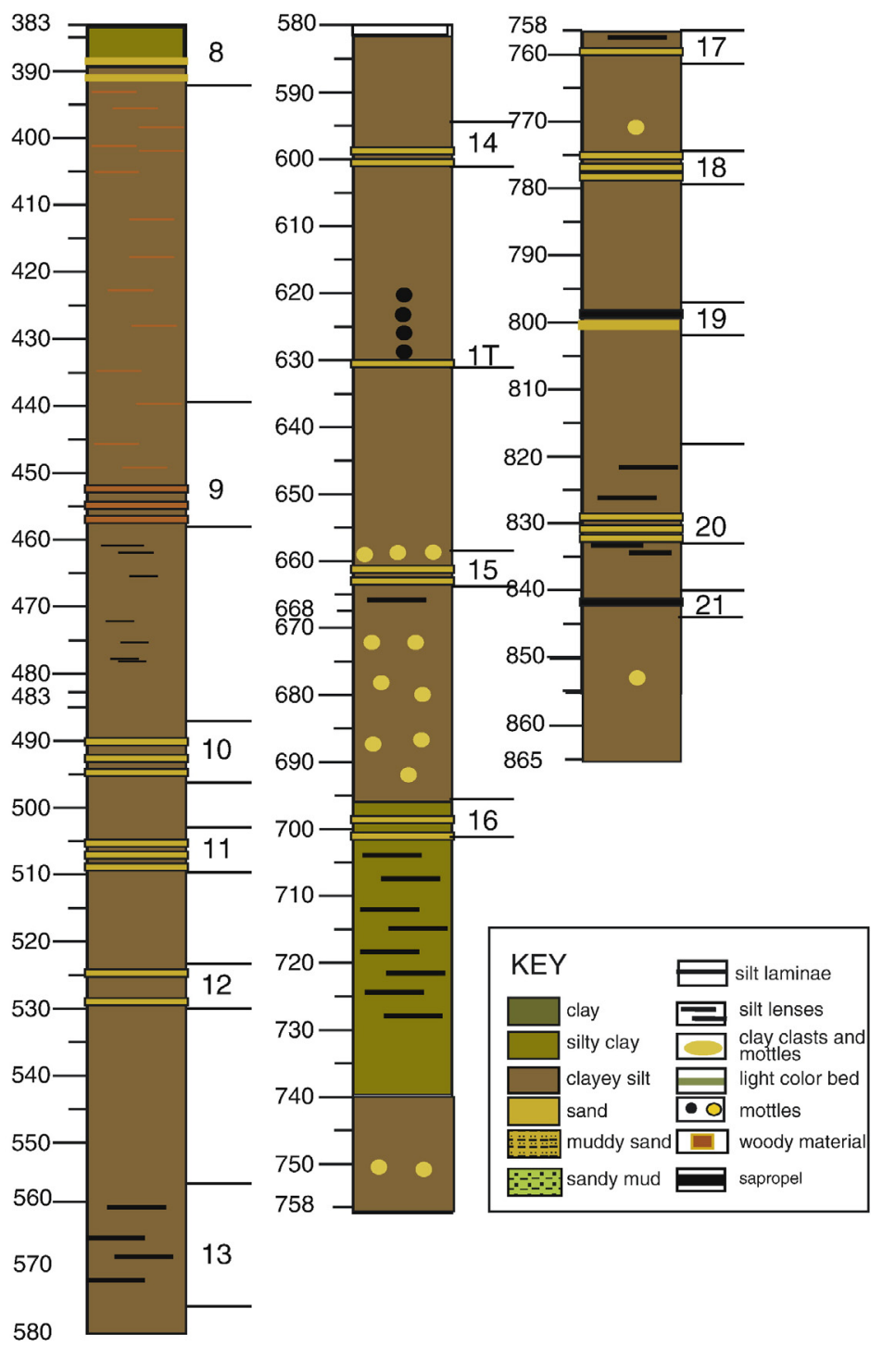

Fig. 4 (continued)

maintains higher concentrations from $\sim 300 \mathrm{~cm}$ to the top of the core (Fig. 5A).

\subsection{Chronology}

\subsubsection{Short-lived radioisotopes}

Excess ${ }^{210} \mathrm{~Pb}$ and ${ }^{137} \mathrm{Cs}$ activities were measured in the sediments from 0 to $30 \mathrm{~cm}$ where their concentrations decreased to background levels (Fig. 6A). The short-lived radioisotope ${ }^{137} \mathrm{Cs}$ is a very useful marker in these sediments because it is dominated by higher concentrations associated to the 1986 Chernobyl event and the 1965 global fallout. Excess ${ }^{210} \mathrm{~Pb}$ is normally characterized by an approximately continuous input and signal. But, in the sediment of Cores KS12, 13, and 18 the signal of ${ }^{210} \mathrm{~Pb}$ and ${ }^{137} \mathrm{Cs}$ shows correspondence between the two shortlived radioisotopes that is possibly due to bioturbation (Fig. 6A). The most reliable chronology is derived from Core KS12 that shows the ${ }^{37}$ Cs 1965 and 1986 global fallout and Chernobyl events at 6 and $2 \mathrm{~cm}$, respectively. The decay of $\mathrm{xs}{ }^{210} \mathrm{~Pb}$ places 1850 at $28-30 \mathrm{~cm}$ in $\mathrm{KS} 12$ (Fig. 6A). A very accurately calculated net sedimentation rate for Core KS12 of $0.22 \mathrm{~cm} / \mathrm{yr}$ was obtained for the upper $25 \mathrm{~cm}$ of the core (Fig. 6B). Based on sedimentation rates calculated from the ${ }^{210} \mathrm{~Pb}$ decay the age of the base of the T-H 1 is early 1900 . But, T-H 1 could have eroded its base so the most solid age for this sedimentation event is derived from ${ }^{37} \mathrm{Cs}$.

\subsubsection{Radiocarbon}

Results obtained from radiocarbon dating provided age constrains for the T-H in Cores KS13, K18, and KS12 (Tables 1, 3; Figs. 7, 8). These ages also permitted to correlate the $\mathrm{T}-\mathrm{H}$ units in all three cores.

\subsubsection{Sedimentation rates}

Sedimentation rates for the past 5000 years were calculated from the slope of the line for the Core KS18 that has preserved the most complete stratigraphic record from al three cores. The averaged rates are 
C

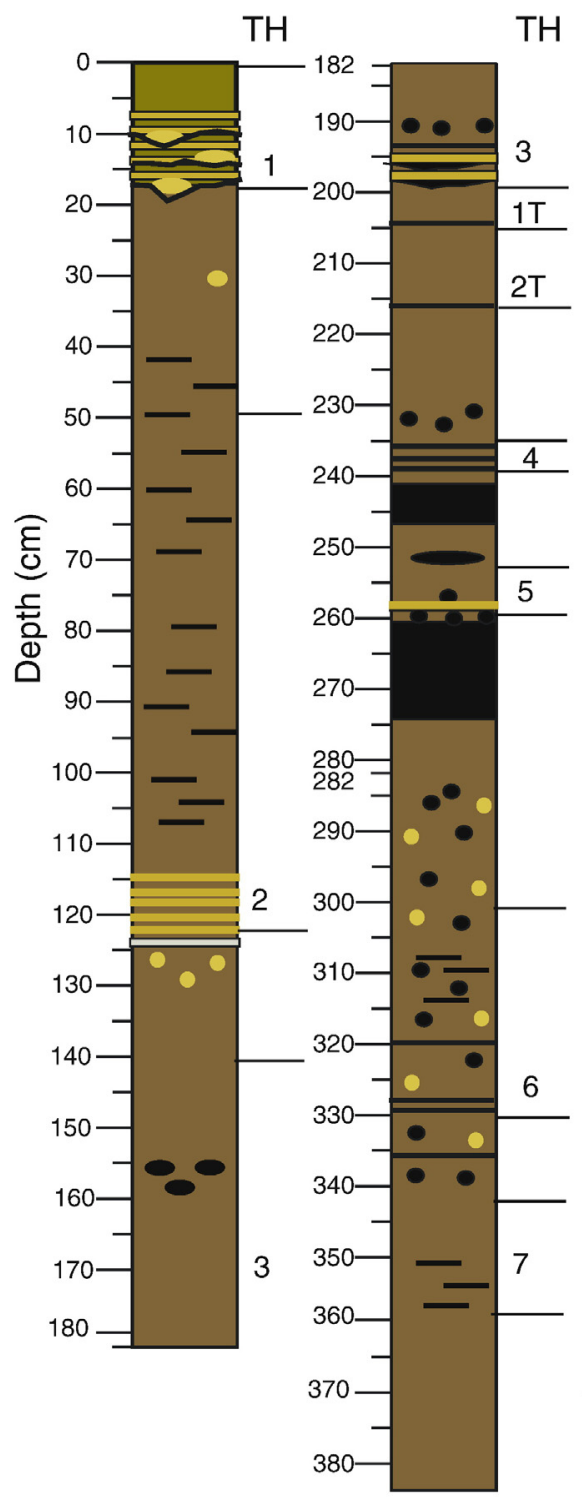

Core KS-12
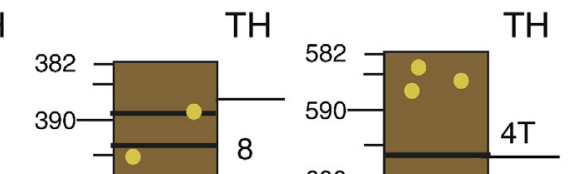

$\mathrm{TH}$

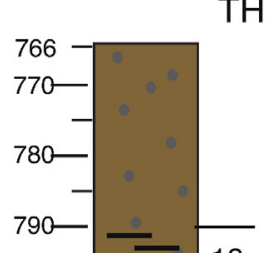

3T

620

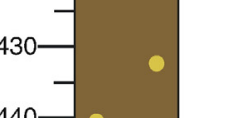

630

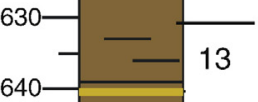

13

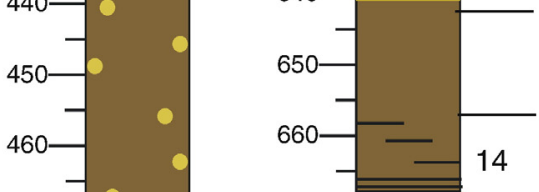

470

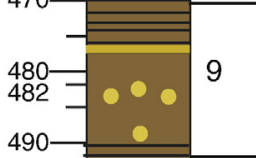

670

680

680

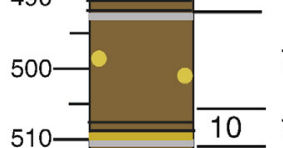

700

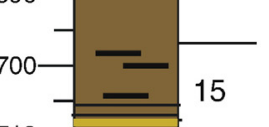

$800-\div \frac{18}{-}$

19

${ }_{830-}^{820-} \square \square$

$840-1$
$850-$
$859-$
$860-$

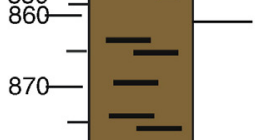

$880-20$

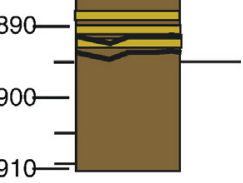

Fig. 4 (continued)

$0.16 \mathrm{~cm} / \mathrm{yr}$. This is slightly less than the core top and could be due to sediment compaction and/or hiatus in sedimentation.

\section{Discussion}

The detailed core analyses permit better quantification and documentation of the relation between sedimentation and earthquakes. In this study we mainly explored the relation between seafloor ruptures and the generation and deposition of $\mathrm{T}-\mathrm{H}$ unit. These sedimentary deposits because of their particular fine structures, grain size variability and elemental composition are easier to date than mass-wasting deposits and can be better linked to seafloor ruptures along the North Anatolia Fault. Once correlated to the historic record of earthquakes the T-H units are referred to as "seismo-turbidites".
6.1. Can a link between sedimentation events and earthquake seafloor ruptures be established?

A good correlation has been established between the three cores from Central Basin for T-Hs 1-6 and historic earthquakes 1963 or 1964, 1343, 860, 740, 557 and 268 (Figs. 7, 8; Table 3). Except for 1963 , the earthquakes being considered were Ms $>6.8$ and are thought to have produced a seafloor rupture (Wells and Coppersmith, 1994) or a surface rupture onshore. A main requirement used for the correlation of the T-H in between cores was that at least two of the cores had comparable radiocarbon ages. An assumption made was that when T-Hs were missing from the record, the youngest above was the one that eroded the older T-H unit. Also used in this study were well-dated T-Hs and their previous correlation with historical earthquakes (McHugh et al., 
2006; Çağatay et al., 2012; Fig. 1). The correlations between Cores KS12 and KS18 were easy to obtain. This was not the case with core KS13 that has two disconformities making $\mathrm{T}-\mathrm{H}$ unit correlations tentative for the pre-historic part of the record (Table 3).

The $\mathrm{T}-\mathrm{H}-1$ can be identified in all three cores. The base of this interval is sharp. The turbidite above is darker in colour, contains closelyspaced laminations of coarse to medium silt, and fines upward into a homogeneous deposit, which is about $10 \mathrm{~cm}$ thick and composed of fine silt (Figs. 3, 6A). Based primarily on ${ }^{37} \mathrm{Cs}, \mathrm{T}-\mathrm{H} 1$ can be linked to the 1963 M6.4 normal fault earthquake epicentre relocated at $95 \mathrm{~km}$ east of the cores (Orgulu, 2011) or the 1964 M6.8 earthquake with a ground rupture about $80 \mathrm{~km}$ south (Ambraseys, 2002a; Emre et al., 2011). Previous studies in Central Basin by McHugh et al. (2006) documented the
1343 earthquake rupture from Core C4 (Fig. 1). Based on radiocarbon ages, lithology (grain size, fine structures and elemental composition) from this study, and as previously documented, $\mathrm{T}-\mathrm{H} 2$ is linked to the 1343 earthquake in all three cores. There is a disconformity in Core $\mathrm{KS} 13$ at $123 \mathrm{~cm}$ at the base of T-H 2 that suggests T-H 3 and T-H 4 are missing and we interpreted that $\mathrm{T}-\mathrm{H} 2$ eroded into the older $\mathrm{T}-\mathrm{H}$ record (Figs. 7, 8, Table 3). The T-H 3 is well correlated to the $860 \mathrm{AD}$ event through radiocarbon age in Core KS12. The 860 AD earthquake was documented in Kumburgaz Basin (Fig. 1; Ambraseys, 2002a). It was proximal enough to have generated a turbidity current and/or mass-wasting sedimentation event in Central Basin. The 860 AD turbidite most likely eroded the sediment beneath in Core KS12 and there is an $~ 500$ year gap separating T-H 3 from T-H 6. Both T-Hs 4 and 5 representative of

A

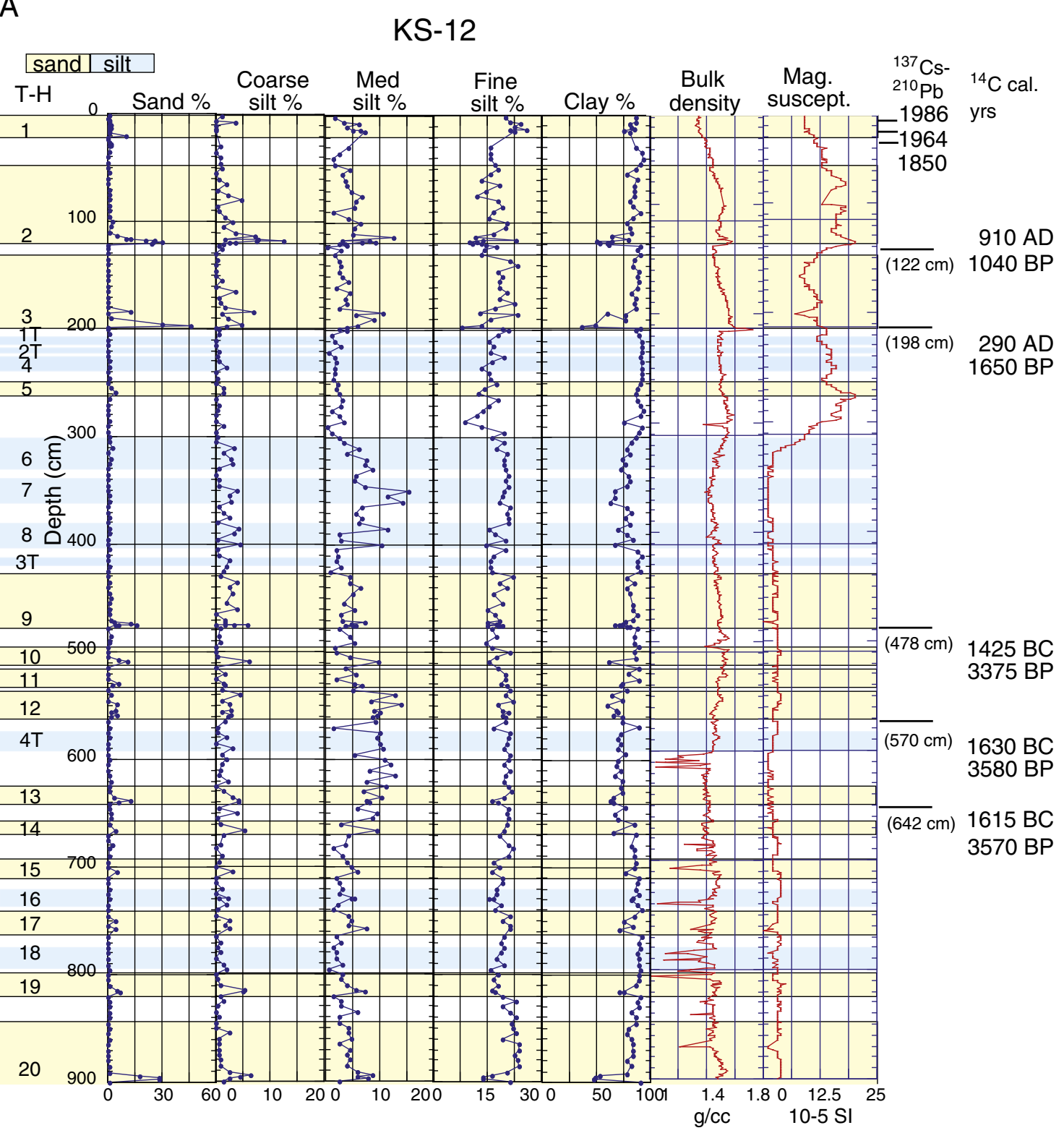

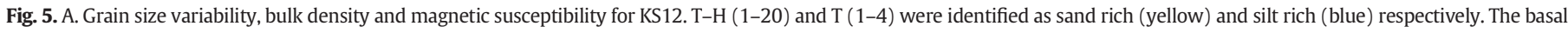

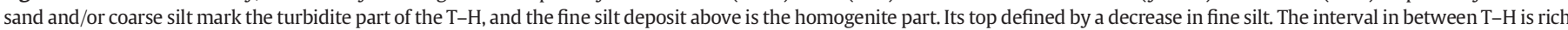

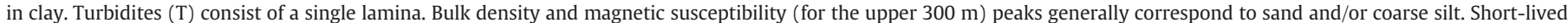

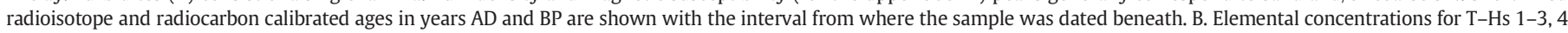

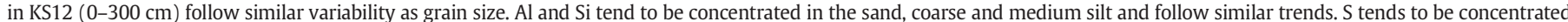

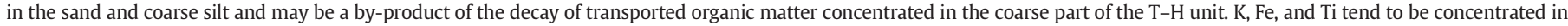

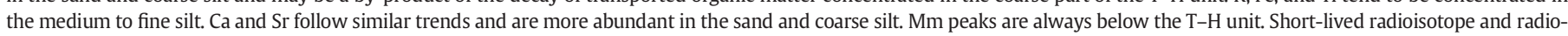
carbon calibrated ages in years AD and BP are shown with the interval from where the sample was dated beneath. 


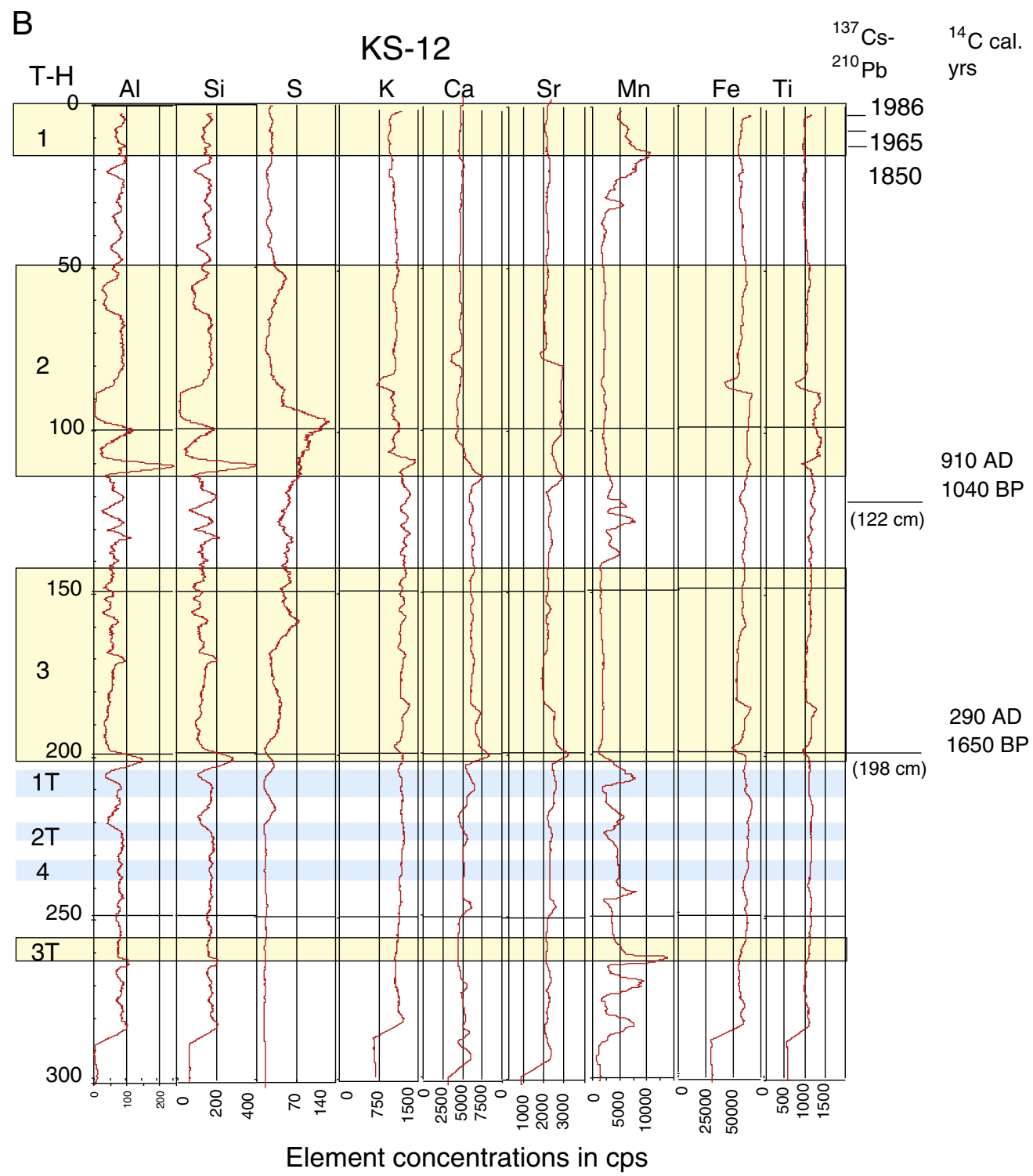

Fig. 5 (continued).

the 740 and 557 historic earthquakes are missing from Core KS12 (Fig. 7, Table 3). But, T-Hs 4 and 5 were linked to the $740 \mathrm{AD}$ and $557 \mathrm{AD}$ earthquakes from radiocarbon ages and the lithology in Core KS18. The T-H 5 was also dated and linked to the $557 \mathrm{AD}$ earthquake in Core KS13. The $740 \mathrm{AD}$ rupture must have been a long rupture because $\mathrm{T}-\mathrm{H}$ units and mass-wasting were associated to this event in Cores KS18 and C4 in Central Basin, Cores K1 and K2 west of Hersek peninsula and Core IZ33 in Izmit Gulf (this study; McHugh et al., 2006). The T-H 6 was linked to the 268 AD earthquake through radiocarbon dating and the lithology. The age of T-H 6 is best constrained from ages obtained from its top in Core KS12 (Fig. 7, Table 3). Based on radiocarbon ages, a good correlation can be found for T-Hs 7-13 in all three cores. But THs 14-18 are missing from Core KS13 (Fig. 8, Table 3). The T-Hs 19-20 have been tentatively correlated in cores KS13, 18 and 12, and T-H 21 has been also tentatively correlated in Cores KS13 and KS18. As a result of hiatuses determined from radiocarbon dating, $\mathrm{T}-\mathrm{Hs}$ are missing in Core KS13. Therefore, new consecutive numbers were given as T-Hs 22-27, that are also much older in age (Fig. 8, Table 3). Core KS13 penetrated deeper, and recovered older strata (Fig. 2). These sedimentation events have not been correlated amongst the cores or to any earthquake record since there are no historical accounts for events older than 2000 years.
These results emphasize that the stratigraphic record of T-Hs can be linked to historical earthquakes and that the Holocene depocenters are the location from where to extract the most complete record. Core KS13 was recovered near a series of steep scarps of the NAF-N and contains several stratigraphic discontinuities most likely due to erosion and deformation along the NAF-N. So when addressing the questions of how earthquake ruptures and sedimentation events correlate spatially in a basin, it is possible to say that there is a correlation. The earthquake deformation is better characterized near the fault, but the timing is better obtained from the T-Hs deposited in the deepest part of a basin where there is less sediment erosion and better continuity of strata.

\subsection{Can sedimentation events be used to identify fault segments?}

The results from this study coupled with the previously published data by McHugh et al. (2006) and Çağatay et al. (2012) indicate that there is a remarkable correlation between the sedimentation record of a basin and the inferred approximate location of the historic earthquake rupture (Ambraseys, 2002a; Ambraseys and Finkel, 1995; Guidoboni and Comastri, 2005; Ambraseys, 2009; Fig. 9). However, the locations of historic earthquake ruptures could have much error since they were guided by historic accounts and not instrumental data. 

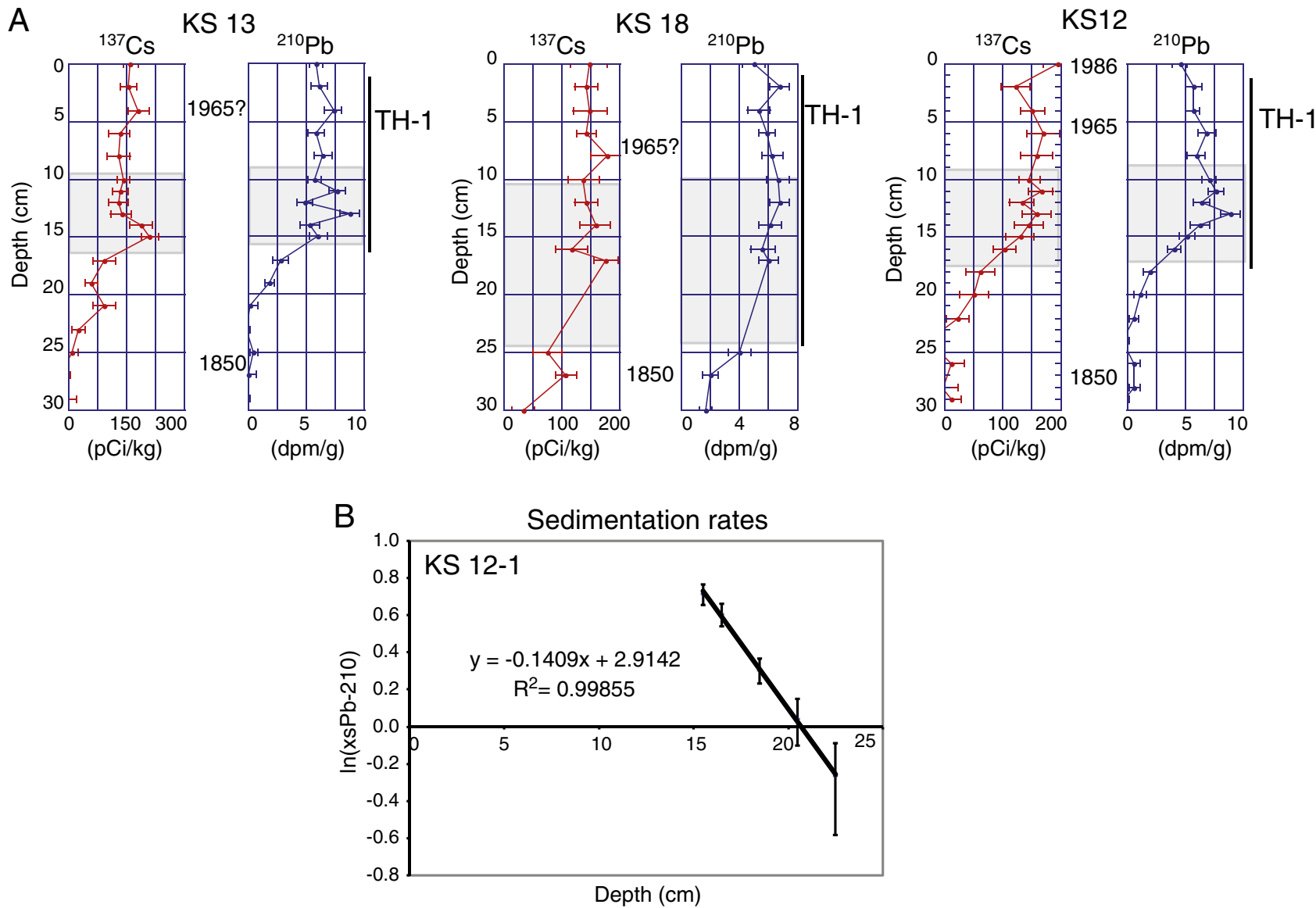

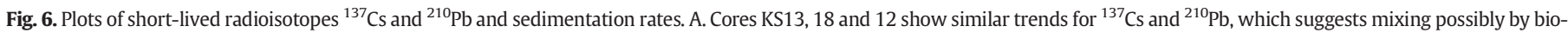

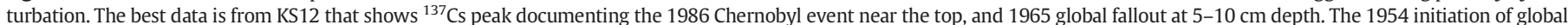

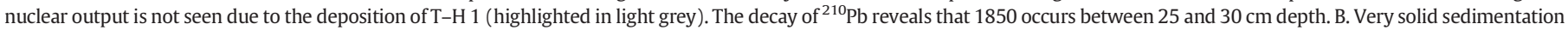
rates of $0.22 \mathrm{~cm} / \mathrm{yr}$ were calculated for Core KS12.

Furthermore, the precise location of the North Anatolian Fault beneath Marmara Sea was not well characterized until after the 1999 Izmit earthquake, so that inferred epicentres from earlier studies may not be well-positioned in Marmara Sea.

The age, sedimentary structures and silt-dominated $\mathrm{T}-\mathrm{H} 1$ suggest a distal source. This is confirmed by its age and correlation to the 1963 or 1964 earthquakes. The 1963 epicentre was 95 km east of Central Basin and the 1964 rupture was $80 \mathrm{~km}$ south (Emre et al., 2011; Orgulu, 2011). The T-H 1 lacks sand and contains wavy laminations and mud clasts that could have been formed by oscillating currents (e.g. Fig. 3A). One possibility to explain the stratigraphy are long waves and seiche-like motions that sorted the sediment as the silt components were settling through the water column and onto the sea-floor. The occurrence of long waves is supported by historic accounts of a $1 \mathrm{~m}$ tsunami that occurred in 1963 along the Gulf of Gemlik coast (Altinok et al., 2011). The age data does not support that T-H 1 was caused by the 1912 Ganos earthquake but rather by the 1963 or 1964 earthquakes. Due to its younger age, there is much more reliable information about the region in which the 1912 occurred in the Gelibolu peninsula (Ambraseys and Finkel, 1995; Rockwell et al., 2001; Ambraseys, 2002a; Aksoy et al, 2010; Meghraoui et al., 2012). But there is less confidence on the extent of this rupture into Marmara Sea. Armijo et al. (2005) proposed that the 1912 rupture extended for $60 \mathrm{~km}$ ending in Central Basin. Previous studies by McHugh et al. (2006) showed evidence for the 1912 NAF rupture in Tekirdag Basin and a fault basin $\sim 4 \mathrm{~km}$ away from the shoreline in Core GA45 (Fig. 1). This small fault basin (40 $\mathrm{m}$ deep, $100 \mathrm{~m}$ wide and $300 \mathrm{~m}$ long) is bisected by the NAF-N and the sub-bottom data clearly show displaced seismic

Table 2

Median and mean for sand, silt and clay derived from the sample's weight percentages.

\begin{tabular}{|c|c|c|c|c|c|c|c|c|}
\hline \multirow[t]{2}{*}{ Core ID } & Sand & Coarse silt & Medium silt & Medium fine silt & Fine silt & Coarse clay & Medium clay & Fine clay \\
\hline & Median & Median & Median & Median & Median & Median & Median & Median \\
\hline KS13 & 0.8 & 1.88 & 5.30 & 12.15 & 19.83 & 22.44 & 14.67 & 18.72 \\
\hline KS18 & 0.5 & 1.60 & 5.10 & 11.78 & 19.58 & 23.30 & 23.30 & 19.05 \\
\hline KS12 & 0.4 & 1.00 & 4.15 & 9.25 & 18.63 & 23.00 & 17.76 & 21.72 \\
\hline \multirow[t]{2}{*}{ Core ID } & Sand & Coarse silt & Medium silt & Medium fine silt & Fine silt & Coarse clay & Medium clay & Fine clay \\
\hline & Mean & Mean & Mean & Mean & Mean & Mean & Mean & Mean \\
\hline KS13 & 4.18 & 2.25 & 6.02 & 12.09 & 19.18 & 21.72 & 14.79 & 19.00 \\
\hline KS18 & 2.34 & 2.30 & 6.46 & 12.41 & 19.87 & 22.42 & 15.14 & 19.11 \\
\hline KS12 & 2.48 & 1.60 & 4.90 & 10.35 & 18.33 & 22.34 & 17.61 & 21.53 \\
\hline
\end{tabular}


Historical Earthquakes

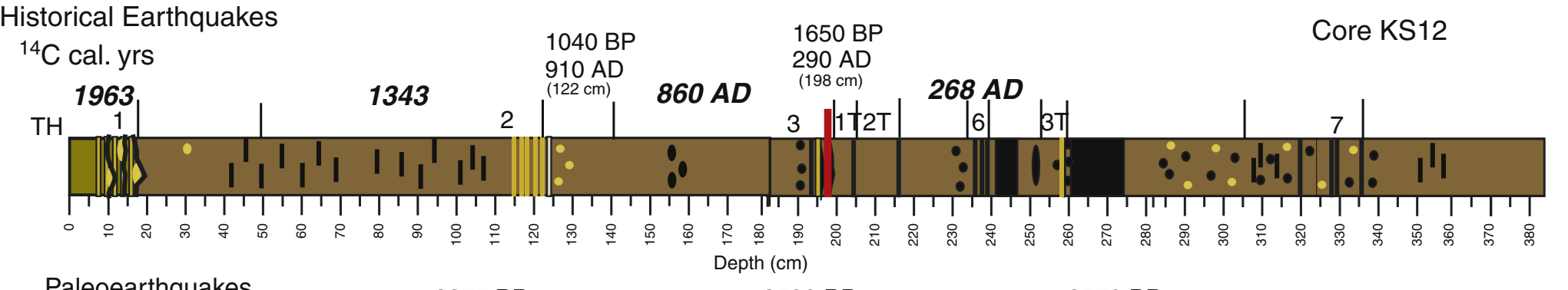

$\begin{array}{lccc}\text { Paleoearthquakes } & 3375 \mathrm{BP} & 3580 \mathrm{BP} & 3570 \mathrm{BP} \\ { }^{14} \mathrm{C} \text { cal. yrs } & 1425 \mathrm{BC} & 1630 \mathrm{BC} & 1615 \mathrm{BC} \\ & (478 \mathrm{~cm}) & (570 \mathrm{~cm}) & (642 \mathrm{~cm})\end{array}$
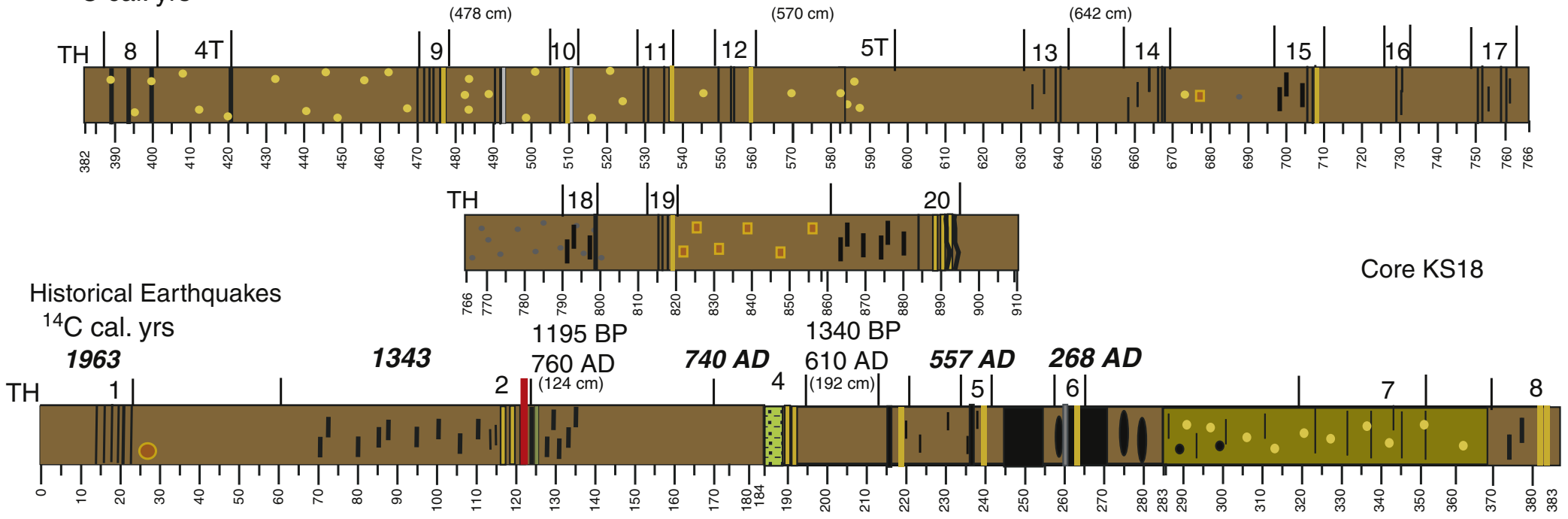

Paleoearthquakes

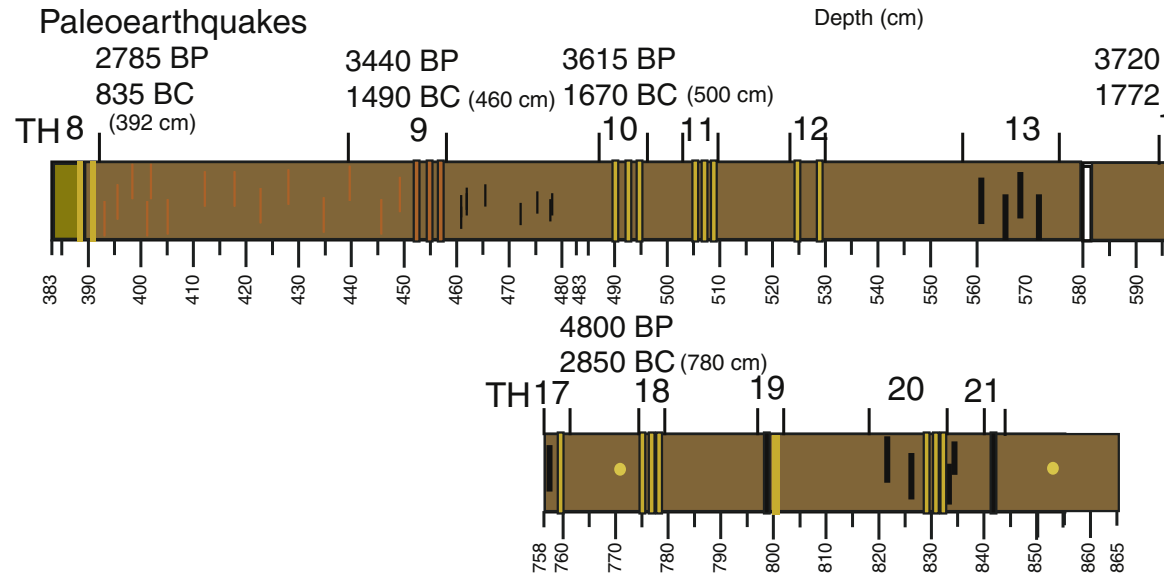

$3720 \mathrm{BP}$

$1772 \mathrm{BC}(605 \mathrm{~cm})$

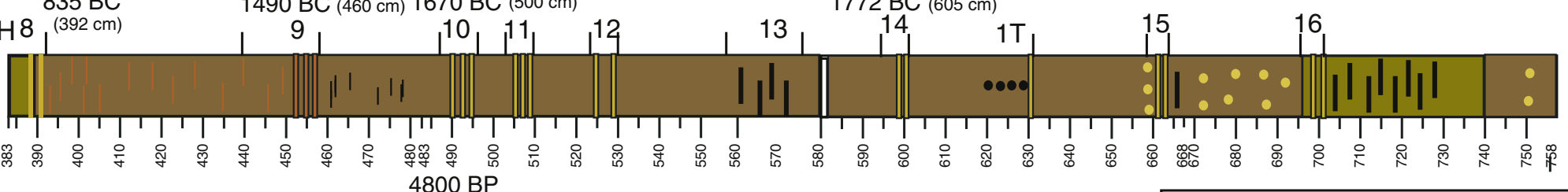

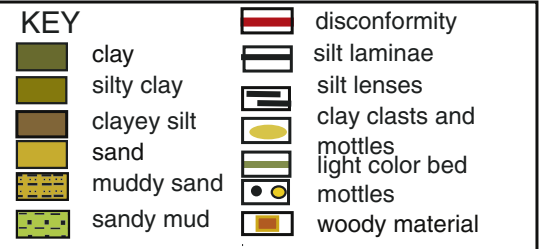

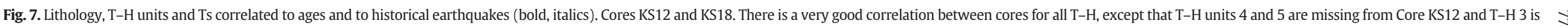
missing from Core KS18. Disconformities are marked as thick red lines. 
Historical

Earthquakes

${ }^{14} \mathrm{C}$ cal. yrs

${ }^{14} \mathrm{C}$ cal.
1963

$\mathrm{TH}$

1

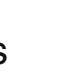

1445 BP Core KS-13

$506 \mathrm{AD}$

557 AD

$1343 \quad(123 \mathrm{~cm}) \quad 557$ AD 268 AD

$\begin{array}{ccc}3295 \mathrm{BP} & 3640 \mathrm{BP} \\ 1340 \mathrm{BC} & 1690 \mathrm{BC} \\ (317 \mathrm{~cm}) & (355 \mathrm{~cm})\end{array}$

Paleoearthquakes

\begin{tabular}{c}
1 \\
Paleoearthquakes \\
\hline
\end{tabular}

$2 \quad 5 \downarrow|6|$

\section{6}

$4910 \mathrm{BP}$

$2960 \mathrm{BC}$

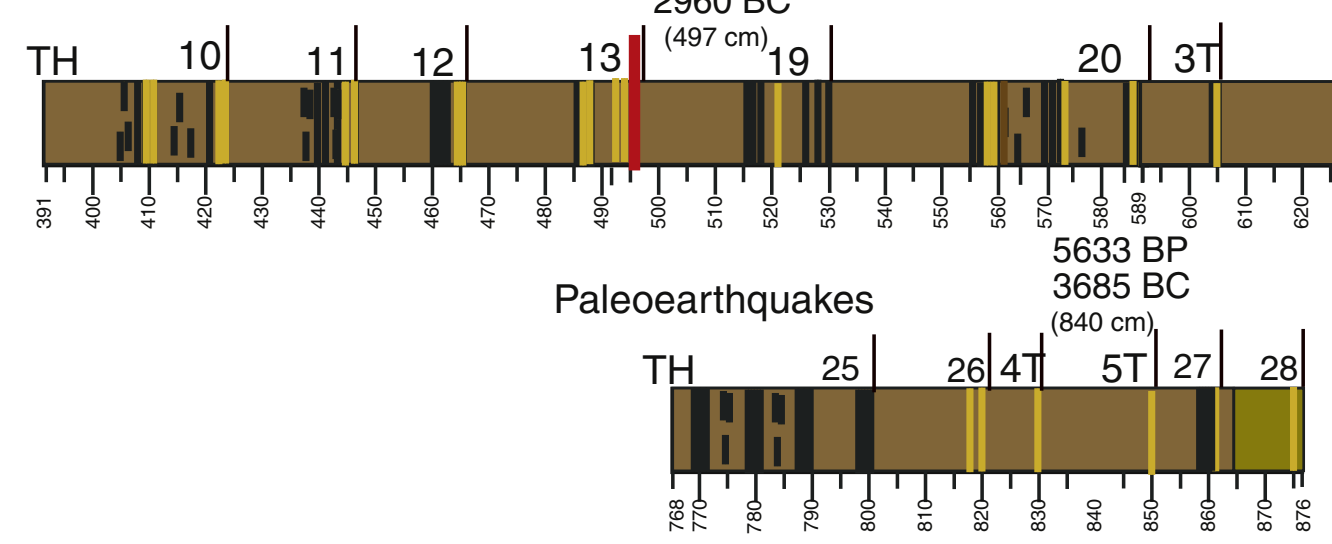

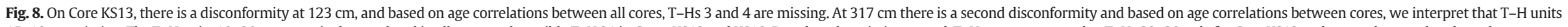

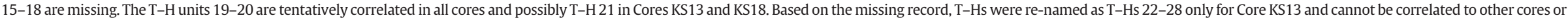
pre-historical earthquakes. This core also recovered the oldest T-Hs at $\sim 5600 \mathrm{cal}$ yrs. BP. 
Table 3

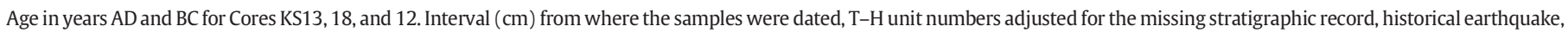
and recurrence interval. disc $=$ discontinuity.

\begin{tabular}{|c|c|c|c|c|c|c|c|c|c|c|}
\hline Core KS-13 & Int. cm & $\mathrm{T}-\mathrm{H}$ & KS-18 & Int. cm & $\mathrm{T}-\mathrm{H}$ & KS-12 & Int. cm & $\mathrm{T}-\mathrm{H}$ & Historic eq. & Int. yrs \\
\hline & & 1 & & & 1 & & & 1 & 1963 or 1964 & \\
\hline \multirow[t]{2}{*}{$1965 \mathrm{AD}$} & 25 & & $1965 \mathrm{AD}$ & 28 & & $1965 \mathrm{AD}$ & 20 & & & 620 \\
\hline & & 2 & & & 2 & & & 2 & 1343 & \\
\hline \multirow[t]{4}{*}{ disc. } & & & & & & $910 \mathrm{AD}$ & 122 & & & 483 \\
\hline & & no 3 & disc. & & no 3 & & & 3 & 860 & \\
\hline & & & $760 \mathrm{AD}$ & 124 & & & & & & 120 \\
\hline & & no 4 & & & 4 & disc. & & no 4 & 740 & \\
\hline \multirow[t]{8}{*}{$505 \mathrm{AD}$} & 123 & & $610 \mathrm{AD}$ & 192 & & & & & & 183 \\
\hline & & 5 & & & 5 & & & no 5 & 557 & \\
\hline & & & & & & & & & & 298 \\
\hline & & 6 & & & 6 & & & 6 & 268 & \\
\hline & & & & & & $290 \mathrm{AD}$ & 198 & & & \\
\hline & & 7 & & & 7 & & & 7 & & \\
\hline & & 8 & & & 8 & & & 8 & & \\
\hline & & & $835 \mathrm{BC}$ & 392 & & & & & & 1125 \\
\hline \multirow[t]{4}{*}{$1340 \mathrm{BC}$} & 317 & & & & & & & & & \\
\hline & & 9 & & & 9 & & & 9 & & \\
\hline & & & $1490 \mathrm{BC}$ & 460 & & $1425 \mathrm{BC}$ & 478 & & & 655 \\
\hline & & 10 & & & 10 & & & 10 & & \\
\hline \multirow[t]{6}{*}{$1690 \mathrm{BC}$} & 355 & & $1670 \mathrm{BC}$ & 500 & & $1630 \mathrm{BC}$ & 570 & & & $\sim 200$ \\
\hline & & 11 & & & 11 & & & 11 & & \\
\hline & & 12 & & & 12 & & & 12 & & \\
\hline & & 13 & & & 13 & & & 13 & & \\
\hline & & & & & 14 & & & 14 & & \\
\hline & & & $1772 \mathrm{BC}$ & 605 & & $2 \sigma-1747 \mathrm{BC}$ & 642 & & & $\sim 50$ \\
\hline \multicolumn{11}{|l|}{ disc. } \\
\hline & & & & & 15 & & & 15 & & \\
\hline & & & & & 16 & & & 16 & & \\
\hline & & & & & 17 & & & 17 & & \\
\hline & & & & & 18 & & & 18 & & \\
\hline \multirow[t]{5}{*}{2960 BC } & 497 & & $2850 \mathrm{BC}$ & 780 & & & & & & $\sim 300$ \\
\hline & & 19 & & & 19 & & & 19 & & \\
\hline & & 20 & & & 20 & & & 20 & & \\
\hline & & 21 & & & 21 & & & & & \\
\hline & & $22-26$ & & & & & & & & \\
\hline 3685 BC & 840 & & & & & & & & & \\
\hline
\end{tabular}

reflectors that were dated from the sediment above as related to the 1912 Ganos earthquake. Drab et al. (2012) documented the 1912 event based on an age model constructed from excess ${ }^{210} \mathrm{~Pb}$ in two cores in Tekirdag Basin and the Central high, respectively, and one core from Central Basin. Results from McHugh et al. (2006) and this study documented a $1912 \mathrm{~T}-\mathrm{H}$ unit in Tekirdag Basin but not in Central Basin where four cores were analysed. Therefore, we support that the 1912 earthquake reached western Central Basin but did not rupture the fault across the entire basin as proposed by Armijo et al. (2005).

The inferred epicentral region for the 1343 earthquake was in the western part of Marmara Sea (Ambraseys, 2002a; Guidoboni and Comastri, 2005; Ambraseys, 2009; Meghraoui et al., 2012; Fig. 9).
Based on radiocarbon ages, lithostratigraphy, thickness of the T-H 2 unit (up to $75 \mathrm{~cm}$ ) and its strong correlation in all three cores, we strongly argue that the 1343 rupture was very proximal if not in Central Basin, and it ruptured one of the faults within the basin (Ambraseys and Finkel, 1995; Ambraseys, 2002a; Guidoboni and Comastri, 2005; Ambraseys, 2009). Two shocks (aftershocks) were reported in 1343 in the Ganos, Gelibolu and the Istanbul regions. Including a tsunami with huge waves that flooded the coast with ships aground and then the lifting of the boats by seawater, which is consistent with long wavelength waves such as tsunami waves. These waves apparently reached the Marmara Sea coast to the Strait of Istanbul (Bosphorus Strait; Aksoy et al, 2010; Altinok et al., 2011). The 1343 earthquake was not

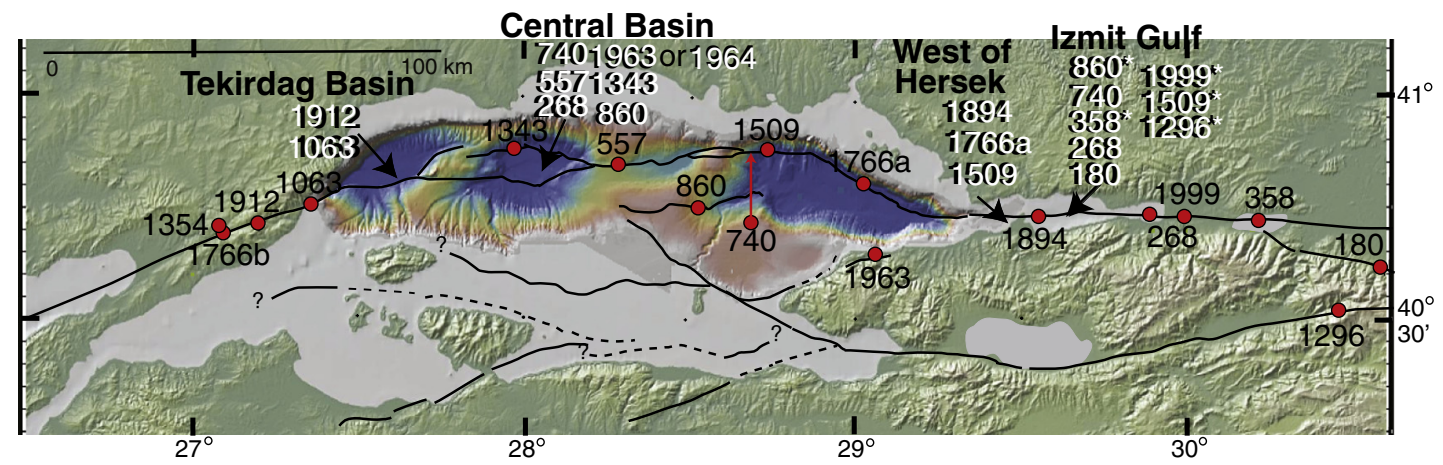

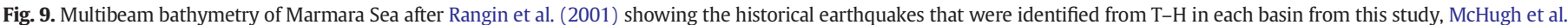

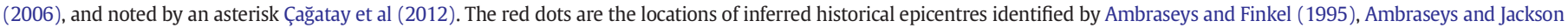

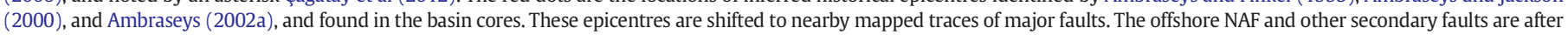
Cormier et al. (2006) and Sorlien et al. (2012), and on land by Emre et al. (2013). 
documented in Tekirdag Basin (McHugh et al., 2006). The ages calculated by Drab et al (2012) for the 1766b and 1343 and/or 1354 events from cores in Tekirdag Basin were obtained from shells and bulk sediment and are too old and not reliable to document these earthquakes (as per Drab et al., 2012). Based on these facts the 1343 rupture did not likely extend into Tekirdag Basin and the Ganos region. Other large shocks were reported for the region in 1344 with significant destruction in the Ganos region, and in 1354 with damage extending from Tekirdag into the Gelibolu region (Guidoboni and Comastri, 2005; Ambraseys, 2009). The destructions in northwestern Marmara Sea coastal villages suggest faulting either along the Ganos fault or further west in the Saros Bay from these events (Meghraoui et al., 2012).

A T-H was linked to the 1063 historic earthquake in Core C8 in Tekirdag Basin (McHugh et al., 2006; Figs. 1, 9). The proximity of this $\mathrm{T}-\mathrm{H}$ to the 1063 rupture is consistent with historic accounts of large shocks from the towns of Tekirdag to Erdek (southernwestern Marmara Sea shore), and damage in towns near western Marmara Sea (Ambraseys, 2009). We did not find evidence of the 1063 earthquake in Central Basin. This agrees with Guidoboni and Comastri (2005) findings that reported little damage to the east, in the Istanbul region, and with Ambraseys (2009) that proposed the epicentre was to the west of Marmara Sea (Fig. 9). This rupture must have been very close to the NAF in Tekirdag Basin possibly extending from onshore and through Tekirdag Basin.

The 557 and 860 historic earthquakes have inferred epicentral regions in eastern Central Basin (Siliviri region) and eastern Kumburgaz Basin, respectively (Fig. 9; Ambraseys and Finkel, 1995; Ambraseys, 2002a). This study found strong evidence for a proximal rupture to Central Basin for the 557 and 860 earthquakes. The T-H units 5 and 3 were correlated to these historic earthquakes by radiocarbon ages, sedimentary structures (multiple sand beds), and are up to $50 \mathrm{~cm}$ thick. This suggests that these deposits are substantial in Central Basin, and possibly define a fault segment extending through Central and Kumburgaz Basins, and possibly reaching Istanbul (Fig. 9). These findings are consistent with a 557 AD tsunami recorded in the Yenikapi Byzantine Harbour and linked to the $557 \mathrm{AD}$ earthquake.

The $740 \mathrm{AD}$ inferred historical epicentre was placed south of eastern Izmit Gulf (Ambraseys and Finkel, 1991) and in southwestern Cinarcik Basin (Ambraseys, 2002a, 2002b). The fault interpretation used in Ambraseys (2002a) has been shown to be incorrect (Armijo et al., 2002). The damage reported extended over a broad region including to the north of Marmara Sea, as far east as Izmit Gulf, and south near the Imrali margin. The $740 \mathrm{AD}$ event was documented by T-Hs from Core KS18 and C4 in Central Basin and IZ33 in Izmit Gulf (this study and McHugh et al., 2006). This indicates that the $740 \mathrm{AD}$ event extended from Izmit Gulf to Central Basin suggesting that this earthquake ruptured at least $170 \mathrm{~km}$ along the NAF-N, including several fault segments. It would have had a larger magnitude than M7.1 as proposed by Ambraseys (2002a) (Wells and Coppersmith, 1994).

The sedimentary deposit correlated to the 268 AD earthquake, T-H 6 , is present in all the cores. But it is very thin averaging $5 \mathrm{~cm}$, and is rich in silt. This suggests a distal source from Central Basin for this historic earthquake and that the $268 \mathrm{AD}$ earthquake did not rupture into Central Basin. These findings are consistent with historic accounts that documented the inferred epicentre in the eastern part of Izmit Gulf (Ambraseys, 2002a). Çağatay et al. (2012) reported the 268 AD earthquake from sediments in a core recovered from the Gulf of Izmit (Fig. 9).

Sedimentary evidence for historic earthquakes that occurred in 1509, 1766a and 1894 was documented west of the Hersek Peninsula (McHugh et al., 2006; Fig. 9). Çağatay et al. (2012) documented the 1509 earthquake in the Gulf of Izmit. The inferred ruptures for the 1509 and 1766a earthquakes, according to Ambraseys and Jackson (2000) and Ambraseys (2002a) occurred near Cinarcik Basin, possibly on the segment of the NAF close to Istanbul. Both were reportedly major earthquakes that affected Istanbul and surroundings. The sediment data supports a rupture of the Istanbul fault segment by the
1509 and 1766a earthquakes. The reported damage for the 1894 earthquake was centred near the region of central and western part of Izmit Gulf and eastern Cinarcik Basin. Ambraseys (2002a) placed the epicentre near Hersek peninsula (Fig. 9) with an estimated magnitude of 7.3 (similar to that of 1999). Amongst the reported damage for the 1894 earthquake were a series of telegraph cables from Tuzla (Istanbul region) and Prince's Islands that broke suggestive of submarine masswasting in those regions (Fig. 1). Thus, it is not surprising to find sedimentary evidence of that earthquake west of Hersek Peninsula and in Cinarcik Basin (McHugh et al., 2006). Based on $\mathrm{xs}{ }^{210} \mathrm{~Pb}$ and ${ }^{137} \mathrm{Cs}$, Drab (2012) documented three events from the sedimentary record of Cores Klg03 and Klg04 that were correlated to the M7.4 1999 Izmit earthquake, the $M=6.41963$ earthquake, and the $M=7.31894$ Cinarcik earthquake. The rupture of the 1999 Izmit earthquake did not reach Cinarcik Basin (Cormier et al., 2006; Gasperini et al., 2011) and this is consistent with Drab's (2012) findings of a very small sedimentary disturbance. The 1963 earthquake is linked to a minor disturbance and a sandy peak that can potentially represent the 1963 M6.4 normal faulting earthquake epicentre southeast of Cinarcik Basin (Orgulu, 2011). The best-defined sedimentary event according to Drab (2012) was correlated to the 1894 earthquake. This is consistent with the reported damage associated to the 1894 earthquake (Ambraseys, 2002a) and McHugh et al.'s (2006) findings west of Hersek Peninsula. Based on radiocarbon ages, other events were identified by Drab (2012) and correlated to the 1509,1343 and 740 AD earthquakes, but there is less confidence in these ages since most (60\%) were obtained from shells that could have been reworked. Also, Cores Klg03 and Klg04 were not recovered from the deepest part of Cinarcik Basin where the most complete Holocene record is expected (Seeber et al., 2006). Nevertheless, it is likely that the sedimentation record of these earthquakes is in Cinarcik Basin. There is evidence for the $740 \mathrm{AD}$ in Izmit Gulf and Central Basin, and the 1343 generated a wave that reached the Marmara Sea coast to the Strait of Istanbul (Bosphorus Strait; Aksoy et al, 2010; Altinok et al., 2011). Eris et al. (2012) that studied a long core recovered from Cinarcik Basin did not find turbidites associated to the 1509, 1766a ruptures or 1894. But, their core (MD2425; Fig. 1) was not recovered from the Cinarcik Basin depocenter either. Additionally, there were no radiocarbon ages obtained by Eris et al. (2012) for the Holocene. Sari and Çağatay (2006) also reported that some of the units from the two cores they studied in Cinarcik Basin (CAG-3 and CG-15; Fig. 1) could be missing. These cores were also not recovered from the Cinarcik Basin Holocene depocenter. Based on this study and others (McHugh et al., 2006; Çağatay et al., 2012; Drab, 2012), there is evidence for the 1509, 1766a, and 1894 earthquake ruptures in Cinarcik Basin (1894, 1509), west of Hersek Peninsula (1509, 1766a, 1894) and for the 1509 and 1999 in Izmit Gulf. It is likely that the 740 AD ruptured a segment of the NAF-N in Cinarcik Basin.

In summary, these findings show a strong correlation between the inferred locations of historical earthquakes and the preservation of turbidite-homogenite units in the basin adjacent to the inferred rupture. Seismically active transform basins such as in the Marmara Sea with frequent earthquakes are constantly shedding sediment and require high-sedimentation rates to preserve a complete "seismo-turbidite" in the stratigraphic record. Therefore, it is not surprising that there is a strong correlation between the location of the inferred historic epicentre and the sedimentary event in the adjacent basin. These basins are constantly shedding sediment ( every 300 years) and it is not expected that a basin distal to the inferred historical rupture will generate a large sedimentary event that is preserved in the stratigraphic record.

6.3. Is there a one-to-one correlation between earthquakes and turbidites? Where does the transported sediment originate?

This and previous studies suggest that there is a very good correlation between earthquake ruptures and turbidites in Marmara Sea. But as documented in other settings, this link is dependent on the 
availability of sediment. In sediment-starved margins such as the carbonate setting of Hispaniola with sedimentation rates of $6 \mathrm{~cm} / 1000$ years $(0.006 \mathrm{~cm} / \mathrm{yr})$, there doesn't appear to be a one-to-one correlation due to the low sediment supply (McHugh et al., 2011b; Rios et al., 2012). In these sediment-starved margins, a substantial time is required to accumulate enough sediment to generate a turbidity current that would transport sediment to a distal depocenter (McHugh et al., 2011a, 2011b; Rios et al., 2012). In margins with low sediment supply $(17 \mathrm{~cm} / 1000$ years, $0.017 \mathrm{~cm} / \mathrm{yr}$ ) such as Cascadia, Goldfinger et al. $(2003,2007,2011)$ was able to correlate turbidites to earthquakes. But the Marmara Sea basins have fairly high Holocene sedimentation rates. This study calculated sedimentation rates of $0.22 \mathrm{~cm}$ per year for the upper $25 \mathrm{~cm}$ of Core KS12 (Fig. 6B), and of $0.16 \mathrm{~cm} / \mathrm{yr}$ for the past 5000 years from Core KS18. So it is not surprising to find a very good correlation between historic earthquakes and T-H units, especially for cores such as these ones that are located in the Holocene depocenters.

The sediments that contribute to the $\mathrm{T}-\mathrm{H}$ units are derived not only from downslope processes but also from resuspension of sediment along the margins of the deep basin. The resuspension of deeper water sediment was documented in Canal du Sud Basin for the 2010 Haiti earthquake based on excess ${ }^{234} \mathrm{Th}$ with a half-life of 24 days (McHugh et al., 2011a). These sedimentation processes are also occurring in the Marmara Sea where the homogenite part of the T-H units is most likely derived from the resuspension of deep-water sediment. The relatively uniform elemental composition and rare foraminifers contained in the homogenite sediments also suggest that much of these deposits were derived from reworked material from the basin margins. In contrast, the sandy part of the turbidite richer in $\mathrm{Ca}$ and $\mathrm{Sr}$ (shell material) must receive sediment from shallow water shelfcanyons sources.

In summary, whether there is a strong correlation between earthquakes and turbidites can to a great extent, be determined by sedimentation rates. The sediment that contributes to the preserved stratigraphic record is derived from downslope transport, mass-wasted sediment related to co-seismic deformation, and resuspended from the margins of the deep basin.

6.4. Can mid- to late-Holocene earthquake- triggered deposits be identified and used to document recurrence intervals?

The radiocarbon ages obtained in the Central Basin cores extended the $\mathrm{T}-\mathrm{H}$ record back to $\sim 6000$ years BP (Tables 1,3 ).

\subsubsection{Historic earthquakes}

Based on this and previous studies of seafloor ruptures in Marmara Sea a tentative recurrence interval can be established for the NAF from Ganos to Cinarcik Basin. The results obtained from Central Basin, the 1912 rupture documented in a "ponded basin", $40 \mathrm{~km}$ east of the inferred Ganos epicentral region and in Tekirdag Basin, and the 1063 historic earthquake documented in Tekirdag Basin provide a record for historic earthquakes for the NAF-N in 1912, 1343, 1063, 860, 740, 557, and 268 (Figs. 1, 9; Table 3; McHugh et al., 2006; Drab et al., 2013). Based on this, the recurrence intervals along the central Marmara segment of the North Anatolia Fault are 569, 280, 203, 120 183, and 289 implying an averaged recurrence of $\sim 274$ years. This is similar to that of 280 years documented by Rockwell et al. (2009); but, faster than the 323 years documented by Meghraoui et al. (2012) from trenching on land. For the Istanbul segment of the fault we documented the 1509 and 1766a historic ruptures, and for the western Izmit segment the $180,268,358,740,860,1296,1509,1766 a, 1894$ and 1999 earthquakes with an average recurrence of 200 years (McHugh et al., 2006; Çağatay et al., 2012; Drab et al., 2012).

\subsubsection{Pre-historic earthquakes}

There is more uncertainty in the ages of the T-H units 11-27 in all three cores than in the younger part of the record. If T-Hs represent pre-historic earthquakes, then the time interval between T-Hs 6 and 8 is $\sim 1000$ years, between T-Hs 9 and 10, 655 years and between THs 10 and 11, 200 years (Figs. 7, 8, Table 3). If we average the recurrence interval between T-Hs 7 and 8, the intervals between earthquakes would be 500, 655 and 200 years, respectively. The range of time for these recurrence intervals is anywhere from 200 years to 655 years. Although variable, these recurrence intervals are in agreement with the historical intervals of the NAF and with recent findings by Çağatay et al. (2012). But more studies are needed to verify these findings.

\subsubsection{Earthquake clusters}

There is a striking series of very closely spaced T-H units 11-14 that span an interval of a $<200$ years in Central Basin Core KS12 and KS18 (Fig. 7, Table 3). One possibility is that one or several T-Hs represent aftershock sequences from a large earthquake. But these T-Hs extend for $1 \mathrm{~m}$ to $2 \mathrm{~m}$ of core, and most importantly, they are separated by hemipelagic sedimentation intervals that average $10 \mathrm{~cm}$ in thickness (e.g., T-H 18, Fig. 8). Hemipelagic sedimentation was calculated at $0.16 \mathrm{~cm}$ per year, so $10 \mathrm{~cm}$ could represent $\sim 60$ years. Therefore aftershocks from a large earthquake are not a probable explanation. Could these closely spaced $\mathrm{T}-\mathrm{Hs}$ represent a period of high seismic activity or clustering in the NAF-N? Earthquake clustering has been previously documented in the NSF east of Marmara Sea where earthquakes have occurred closely spaced in time from 1939 to 1999. These earthquakes were spaced geographically but there was overlap in the damage they caused similar to the sedimentation record preserved in the Marmara Sea basins (Stein et al., 1997; Barka, 1999).

These findings about earthquake clusters, if real, may explain the lack of large ruptures in Central Basin since 1343 where large shocks were reported for the region in 1344 and in 1354. Based on Kurt et al. (2013) and Grall et al (2013), there could be $18 \mathrm{~mm} / \mathrm{yr}$ of slip and 12 $\mathrm{m}$ of strain accumulation along the NAF in Central Basin. But this does not mean that there will be $12 \mathrm{~m}$ of slip in one large rupture. If earthquakes were closely-spaced in time $(1343,1344,1354)$ there could have been several metres of slip on each of the closely-spaced in time earthquakes. More questions than answers arise from these findings that will need to be addressed by continued submarine paleoseismology studies of the NAF. Are these T-H triggered by earthquakes related to one or several shallow faults of the NAF in or near the Central Basin segment? There are multiple fault strands in Central Basin (Fig. 1). Could the T-Hs represent activity of the several faults seen on the chirp profiles (Figs. 1,2)? Or ruptures of the north border and south border faults in Central Basin? The historical and T-H records indicate that ruptures are segmented. For example, our data suggest that Ganos-Tekirdag and Central Basin may constitute two different segments. What is the spatial extent of these segments? Closely-spaced long cores need to be taken in each basin and in different depositional environments, including the Holocene depocenters to test these possibilities and continue to make progress in the field of submarine paleoseismology.

\section{Conclusions}

A multiproxy approach (grain size, elemental analyses, physical properties) calibrated to radioisotope dating was used to identify $\mathrm{T}-\mathrm{H}$ units and correlate them to historic earthquakes. These sedimentation events are complex and the stratigraphy suggests secondary processes, such as multiple failures, sediment resuspension, and/or reworking by long wave, seiche-like. But, such processes are likely in the closecontour shape basins of Marmara Sea where small tsunamis have been documented from historical accounts.

These results show that there is a remarkable correlation between the inferred location of the historic earthquake rupture and the seismo-turbidite record in the basin adjacent to the fault rupture. A good correlation was obtained for T-H units in Central Basin and historic earthquakes that occurred in 1963 or 1964, 1343, 860, 740, 557 and 268. Overall, the sedimentation record for the Marmara Sea basins 
suggests that there is a gap in the earthquakes in Central Basin since 1343. Earthquake clustering $(1343,1344,1354)$ could have produced several metres of slip and diminished strain accumulation along the NAF in Central Basin. The 740 AD earthquake could have ruptured multiple segments of the NSF from Izmit Gulf to Central Basin.

The best location for obtaining a well-preserved record of $\mathrm{T}-\mathrm{H}$ is in the deepest part of a basin where $~ 80 \%$ of the sediments are composed of $\mathrm{T}-\mathrm{H}$ units. Generally there is a good correlation between the T-H units and earthquake sea floor ruptures in cores from the depocentral area. The cores proximal to the fault are best for identifying $\mathrm{T}-\mathrm{H}$ units since more sand is available. But at this location there is also more erosion and deformation due to fault activity and downslope sediment transport processes.

$\mathrm{T}-\mathrm{H}$ can be used to identify pre-historic earthquake ruptures if they can be correlated in more than one core in a basin. This study is a first step to tentatively extend the record of possible earthquakes back in time to 6000 years BP. An unexpected finding was the occurrence of four $\mathrm{T}-\mathrm{H}$ units within a very short time period of 142 years spanning from $1772 \mathrm{BC}$ to $1630 \mathrm{BC}$. The possibility of earthquake clustering is seriously being considered and should be further investigated in the future. This new finding has the potential of contributing substantially to future progress in the field of submarine paleoseismology.

\section{Acknowledgements}

The National Science Foundation OCE-0328119 supported this work. NOSAMS, Woods Hole where the radiocarbon analyses were conducted. This manuscript was greatly improved thanks to two anonymous reviewers. We are grateful to them. The laboratory of Dr. R. Bopp from Rensselaer Polytechnic University for short-lived radioisotopes analyses. Queens College undergraduate students: C. Aquino, M. Gatica, J. Rios. From ITU Dursun Acar and Gulsen Uçarkus.

\section{Appendix A. Supplementary data}

Supplementary data to this article can be found online at http://dx. doi.org/10.1016/j.margeo.2014.03.005.

\section{References}

Aksoy, M.E., Meghraoui, M., Vallee, M., Cakir, Z., 2010. Rupture characteristics of the A.D. 1912 Murefte (Ganos) earthquake segment of the North Anatolian fault (western Turkey). Geology 38, 991-994. http://dx.doi.org/10.1130/G13447.1.

Altinok, Y., Alpar, B., Ozer, N., Aykurt, H., 2011. Revision of the tsunami catalogue affecting Turkish coasts and surrounding regions. Natural Hazards and Earth System Sciences 11, 273-291.

Altunel, E., Meghraoui, M., Akyüz, H.S., Dikbas, A., 2004. Characteristics of the 1912 coseismic rupture along the North Anatolian Fault Zone (Turkey): implications for the expected Marmara earthquake. Terra Nova 16, 198-204.

Ambraseys, N.N., 2002a. The seismic activity in the Marmara Sea region over the last 2000 years. Bulletin of the Seismological Society of America 92, 1-18.

Ambraseys, N.N., 2002b. Seismic sea-waves in the Marmara Sea region during the last 20 centuries. Journal of Seismology 6, 571-578.

Ambraseys, N.N., 2009. Earthquakes in the Mediterranean and Middle East: A Multidisciplinary Study of Seismicity up to 1900. Cambridge University Press, Cambridge, U. K. (947 pp.).

Ambraseys, N., Finkel, C., 1991. Long-term seismicity of Istanbul and of the Marmara Sea region. Terra Nova 3, 527-539.

Ambraseys, N.N., Finkel, C.F., 1995. The Seismicity of Turkey and Adjacent Areas - A Historical Review, 1500-1800. EREN, Istanbul (240 pp.).

Ambraseys, N.N., Jackson, J.A., 2000. Seismicity of the Sea of Marmara (Turkey) since 1500. Geophysical Journal International 141, F1-F6.

Appleby, P.G., 2000. Radiometric dating of sediment records in European mountain lakes. In: Lami, A., Cameron, N., Korhola, A. (Eds.), Paleolimnology and Ecosystem Dynamics at Remote European Alpine Lakes. Limnology, 59, pp. 1-14.

Armijo, R., Meyer, B., Navarro, S., King, G.C.P., Barka, A.A., 2002. Asymmetric slip partitioning in the Sea of Marmara pull-apart: a clue to propagation processes of the North Anatolian Fault? Terra Nova 14, 80-86.

Armijo, R., Pondard, N., Meyer, B., Uçarkus, G., Mercier de Lepinay, B., Malavieille, J., Dominguez, S., Gustcher, M.-A., Schmidt, S., Beck, C., Çă̆atay, M.N., Çakir, Z., Imren, C., Eris, K., Natalin, B., Özalaybey, S., Tolun, L.G., Lefèvre, I., Seeber, L., Gasperini, L. Rangin, C., Emre, Ö., Sarikavak, K., 2005. Submarine fault scarps in the Sea of Marmara pull-apart (North Anatolian Fault): implications for seismic hazard in Istanbul. Geochemistry, Geophysics, Geosystems 6, Q06009.

Barka, A.A., 1999. The 17 August 1999 Izmit earthquake. Science 285, 1858-1859.

Barka, A.A., Kadinsky-Cade, K., 1988. Strike-slip fault geometry in Turkey and its influence on earthquake activity. Tectonics 7, 663-684.

Barnes, P.M., 2009. Postglacial (after $20 \mathrm{ka}$ ) dextral slip rate of the offshore Alpine fault, New Zealand. Geology 37, 3-6.

Bartolome, R., Gracia, E., Stich, D., Martinez-Loriente, S., Klaeschen, D., Mancilla, F. de L., Lo Iacono, C., Danobeitia, J.J., Zitellini, N., 2012. Evidence for active strike-slip faulting along the Eurasia-Africa convergence zone: implications for seismic hazard in southwest Iberian margin. Geology 40, 495-498.

Beck, C., Mercier de Lepinay, B., Schneider, J.L., Cremer, M., Cağatay, M.N., Wendenbaum, E., Boutareaud, S., Menot, G., Schmidt, S., Weber, O., Eris, K.K., Armijo, R., Meyer, B. Pondard, N., Gutscher, M.A., MARMARACORE cruise party, 2007. Late Quaternary co-seismic sedimentation in the Sea of Marmara's deep basins. Sedimentary Geology 199, 65-89.

Buesseler, K.O., Livingston, H.D., Honjo, S., Hay, B.J., Manganini, S.J., Degens, E., Ittekkot, V., Izdar, E., Konuk, T., 1987. Chernobyl radionuclides in a Black Sea sediment trap. Nature 329, 825-828.

Çağatay, M.N., Erel, L., Bellucci, L.G., Polonia, A., Gasperini, L., Eris, K.K., Sancar, U., Biltekin, D., Uçarkus, G., Ulgen, U.B., Damci, E., 2012. Sedimentary earthquake records in the Izmit Gulf, Sea of Marmara, Turkey. Sedimentary Geology. http://dx.doi.org/10 1016/j.sedgeo.2012.10.001.

Cormier, M.-H., Seeber, L., McHugh, C.M.G., Polonia, A., Çağatay, M.N., Emre, O., Gasperini, L., Görür, N., Bortoluzzi, G., Bonatti, E., Ryan, W.B.F., Newman, K.R., 2006. The North Anatolian fault in the Gulf of Izmit (Turkey): Rapid vertical motion in response to minor bends of a non-vertical continental transform. Journal of Geophysical Research 111, B04102. http://dx.doi.org/10.1029/2005JB003633.

Crusius, J.F., 1992. Evaluating the Mobility of ${ }^{137} \mathrm{Cs},{ }^{239}+{ }^{240} \mathrm{Pu}$ and ${ }^{210} \mathrm{~Pb}$ from their Distributions in Laminated Sediments. (Ph.D. Dissertation) Columbia University 261.

Drab, L., 2012. Marine Paleoseismology and Paleomagnetism in Marmara Sea. (Ph.D. Thesis) Paris Sud University 113-127.

Drab, L., Hubert-Ferrari, A., Schmidt, S., Martinez, P., 2012. The earthquake record in the western part of the Sea of Marmara, Turkey. In: Pantosi, D. (Ed.), Natural Hazards and Earth System Sciences, Special Issue "Subaqueous Paleoseismology", pp. 1235-1254. http://dx.doi.org/10.5194/nhess-12-2012.

Emre, O., A. Dogan, S. Ozalp, C. Yildirim, 2011, 1:250,000 scale Active Fault Map Series of Turkey, Bandirma (NK 35-11b) Quadrangle, Serial number: 3, General Directorate of Mineral Research and Exploration, Ankara-Turkey.

Emre, O., Duman, T. Y., Ozalp, S., Elmaci, H., Olgun, S, Saroğlu, F., 2013. Active Fault Map of Turkey. Special Publication Series 30: General Directorte of Mineral Research and Exploration (MTA), Ankara, Turkey, scale 1:125000, 1 sheet, ISBN: 978-605-5310-56-1.

Eremeev, V.N., Ivanov, L.M., Kirwan, A.D., Margolina, T.M., 1995. Amount of ${ }^{137} \mathrm{Cs}$ and ${ }^{134} \mathrm{Cs}$ radionuclides in the Black Sea produced by the Chernobyl accident. Journal of Environmental Radioactivity 27, 49-63.

Eris, K.K., Çağatay, N., Beck, C., Mercier de Lepinay, B., Campos, C., 2012. Late-Pleistocene to Holocene sedimentary fills of the Cinarcik Basin of the Sea of Marmara. Sedimentary Geology 281, 151-165.

Expedition 317 Scientists, 2011. Expedition 317 Summary. In: Fulthorpe, C.S., Hoyanagi, K. Blum, P., Expedition 317 Scientists (Eds.), Proc. IODP, 317. Integrated Ocean Drilling Program Management International, Inc., Tokyo. http://dx.doi.org/10.2204/iodp. proc.317.101.2011.

Gasperini, L., Polonia, A., Çağatay, M.N., Bortoluzzi, G., Ferrante, V., 2011. Geological slip rates along the North Anatolian Fault in the Marmara Sea. Tectonics 30, TC6001.

Géli, L., Henry, P., Andre, C., Zitter, T., Çağatay, N., Mercier de Lepinay, B., LePichon, X., Sengor, A.M.D., Gorur, N., Natalin, B., Ucarkus, G., Ozeren, S., Volker, D., Gasperini, L. Bourlanger, S., MarNaut Scientific Party, 2008. Gas emissions and active tectonics within the submerged section of the North Anatolia Fault zone in the Sea of Marmara. Earth and Planetary Science Letters 274, 34-39.

Goldfinger, C., 2011. Submarine paleoseismology based on turbidite records. Annual Review of Marine Science 3, 35-66.

Goldfinger, C., Nelson, C.H., Johnson, J.E., 2003. Holocene earthquake records from the Cascadia subduction zone and northern San Andreas fault based on precise dating of offshore turbidites. Annual Review of Earth and Planetary Sciences $31,555-577$.

Goldfinger, C., Morey, A.E., Nelson, C.H., Gutierez-Pastor, J., Johnson, J.E., Karabanov, E., Eriksson, A., Shipboard scientific party, 2007. Rupture lengths and temporal history of significant earthquakes on the offshore and north coast segments of the Northern San Andreas Fault based on turbidite stratigraphy. Earth and Planetary Science Letters 254, 9-27.

Gracia, E., Vizcaino, A., Escutia, C. Asioi, A. Rodes, A Pallas, R. Garcia-Orellana, J., Lebreiro, S., Goldfinger, C., 2010. Holocene earthquake record offshore Portugal (SW Iberia): testing turbidite paleoseismology in a slow-convergence margin. Quaternary Science Reviews 29, 1156-1172.

Grall, C., Herny, P., Thomas, Y., Westbrook, G.K., Çăgatay, M.N., Marsset, B., Saritas, H., Çifici, G., Geli, L., 2013. Slip rate estimations along the western segment of the Main Marmara Fault over the last 405-490 ka by correlating mas transport deposits. Tectonics 32, 1-15.

Guidoboni, E., Comastri, A., 2005. Catalogue of Earthquakes and Tsunamis in the Mediterranean Area from the 11 th to the 15 th Century. Ist. Naz. Di Geofis. E Vulcanolgia Rome.

Hakimian, A., 2012. Sedimentation and Earthquakes in the Eastern Mediterranean Sea: Characteristics and Depositional Processes. (Masters of Arts Thesis) Queens College, City University of New York (75 pp.).

Hornbach, M.J., Braudy, N., Briggs, R.W., Cormier, M.-H., Davis, M.B., Diebold, J.B., Dieudonne, N., Douilly, R., Frohlich, C., Gulick, S.P.S., Johnson, H.E., Mann, P., 
McHugh, C.M.G., Ryan-Mishkin, K., Prentice, C.S., Seeber, L., Sorlien, C.C., Steckler, M.S Symithe, S.J., Taylor, F.W., Templeton, J., 2010. High tsunami frequency as a result of combined strike-slip faulting and coastal landslides. Nature Geoscience 3, 783-788.

Hubert-Ferrari, A., Barka, A.A., Jacques, E., Nalbant, S.S., Meyer, B., Armijo, R., Tapponier, P. King, G.C.P., 2000. Seismic hazard in the Marmara Sea region following the 17 August 1999 Izmit earthquake. Nature 404, 269-273.

Ken-Tor, R., Agnon, A., Enzel, Y., Stein, M., 2001. High-resolution geological record of historic earthquakes in the Dead Sea basin. Journal of Geophysical Research 106 2221-2234.

Kurt, H., Sorlien, C.C., Seeber, L., Steckler, M.S., Shillington, D.J., Cific, G., Cormier, M.-H. Dessa, J.-X., Atgin, O., Dondurur, D., Demirbag, E., Okay, S., Imren, C., Guracay, S., Carton, H., 2013. Steady late quaternary slip rate on the Cinarcik section of the North Anatolian Fault near Istanbul, Turkey. Geophysical Research Letters 40 (1-5). http://dx.doi.org/10.1002/grl.50882.

Kuscu, I, Okamura, M. Matsuoka, H., Yamamori, K, Awata, Y, Ozalp, S., 2009. Recognition of active faults and stepover geometry in Gemlik Bay, Sea of Marmara, NW Turkey. Marine Geology 260, 90-101.

Lorenzoni, L., Benitez-Nelson, C.R., Thunell, R.C., Hollander, D., Varelan, R., Astor, Y. Audemard, F.A., Muller-Karger, F.E., 2012. Marine Geology. http://dx.doi.org/10. 1016/j.margeo.2011.12.009.

Marco, S., Agnon, A., 1995. Prehistoric earthquake deformations near Masada, Dead Sea graben. Geology 23, 695-698.

Masson, D.G., Arzola, R.G., Wynn, R.B., Hunt, J.E., Weaver, P.P.E., 2011. Seismic triggering of landslides and turbidity currents offshore Portugal. Geochemistry, Geophysics, Geosystems 12,1-19. http://dx.doi.org/10.1029/2011GC003839.

McClusky, S.C., Bassalanian, S., Barka, A.A., Demir, C., Ergintav, S., Georgiev, I., Gurkan, O., Hamburger, M., Hurst, K., Kahle, H.-G., Kastens, K., Kekelidze, G., King, R.W., Kotzev, V., Lenk, O., Mahmoud, S., Mishin, A., Nadariya, M., Ouzounis, A., Paradissis, D., Peter, Y. Prilepin, M., Reilinger, R.E., Sanli, I., Seeger, H., Tealeb, A., Toksöz, M.N., Veis, G., 2000. Global Positioning System constraints on plate kinematics and dynamics in the eastern Mediterranean and Caucasus. Journal of Geophysical Research 105, 5695-5719.

McHugh, C.M.G., Seeber, L., Cormier, M.H., Dutton, J., Cağatay, M.N., Polonia, A., Ryan, W.B. F., Görür, N., 2006. Submarine earthquake geology along the North Anatolia Fault in the Marmara Sea, Turkey: a model for transform basin sedimentation. Earth and Planetary Science Letters 248, 661-684

McHugh, C., Seeber, L., Braudy, N., Cormier, M.-H., Davis, M., Dieudonne, N., Deming, J. Diebold, J., Douilly, R., Gulick, S., Hornbach, M., Johnson, H., Mishkin, K., Sorlien, C. Steckler, M., Symithe, S., Templeton, J., 2011a. Offshore sedimentary effects of the 12 January Haiti earthquake. Geology 39 (8), 723-726. http://dx.doi.org/10.1130/ G31815.1.

McHugh, C.M., Seeber, L., Cormier, M.-H., Hornbach, M.H., Momplaisir, R., Waldhaourser, F., Sorlien, C., Steckler, M., Gulick, S., 2011b. A seismo-tectonic signal from offshore sedimentation: the 2010 Haiti earthquake and prior events. Abstract T33G-2492, AGU Fall Meeting, San Francisco CA.

Meghraoui, M., Aksoy, M.E., Akyuz, H.S., Ferry, M., Dikbas, A., Altunnel, E., 2012 Paleoseismology of the North Anatolia Fault at Guzelkoy (Ganos segment, Turkey): Size and recurrence time of earthquake ruptures west of the Sea of Marmara. Geochemistry, Geophysics, Geosystems 13, 1-26.

Migowski, C., Agnon, A., Bookman, R., Negendank, J.F.W., Stein, M., 2004. Recurrence pattern of Holocene earthquakes along the Dead Sea transform revealed by varvecounting and radiocarbon dating of lacustrine sediments. Earth and Planetary Science Letters 222, 301-314.

Nakajima, T., Kanai, Y., 2000. Sedimentary features of seismoturbidites triggered by the 1983 and older historical earthquakes in the eastern margin of the Japan Sea. Sedimentary Geology 135, 1-19.

Noda, A., TuZino, T., Kanai, Y., Furukawa, R., Uchida, J., 2008. Paleoseismicity along the southern Kuril Trench deduced from submarine-fan turbidites. Marine Geology 204 $73-90$.

Orgulu, G., 2011. Seismicity and source parameters for small-scale earthquakes along the splays of the North Anatolian Fault (NAF) in the Marmara Sea. Geophysical Journa International 184, 385-404.

Parsons, T., Toda, S., Stein, R.S., Barka, A.A., Dieterich, J.H., 2000. Heightened odds of large earthquakes near Istanbul: an interaction-based probability calculation. Science 288 661-665.

Pouderoux, H., Lamarche, G., Proust, J.-N., 2012. Building a 18,000 year-long paleoearthquake record from detailed deep-sea turbidite characterization in Poverty Bay, New Zealand. Natural Hazards and Earth System Sciences 12, 2077-2101.
Rangin, C., Demirbag, E., Imren, C., Crusson, A., Normand, A., Le Drezen, E., Le Bot, A., 2001. Marine Atlas of the Sea of Marmara (Turkey). Ifremer.

Reilinger, R.E., Toksöz, M.N., McClusky, S.C., Barka, A.A., 2000. 1999 Izmit, Turkey earthquake was no surprise. GSA Today 10, 1-6.

Reilinger, R., McClusky, S., Paradissis, D., Ergintav, S., Vernant, P., 2010. Geodetic constraints on the tectonic evolution of the Aegean region and strain accumulation along the Hellenic subduction zone. Tectonophysics 488, 22-30.

Rios, J., McHugh, C.M., Seeber, L., Blair, S., Sorlien, C., 2012. Latest Pleistocene to Holocene evolution of the Baie de Port au Prince, Haiti. AGU Fall Meeting Abstract \# T41A2572.

Rockwell, T.K., Barka, A.A., Dawson, A.G., Akyüz, H.S., Thorup, K., 2001. Paleoseismology of the Gazikoy-Saros segment of the North Anatolian fault, northwest Turkey: comparison of the historical and paleoseismic records, implications of regional seismic hazard, and models of earthquake recurrence. Journal of Seismology 5, 433-448.

Rockwell, T.K. et al., 2009. Paleoseismology of the North Anatolian Fault near the Marmara Sea: implications for fault segmentation and seismic hazard. In: Reicherter, K., Michetti, A.M., Silva, P.G. (Eds.), Paleoseismology: Historical and Prehistorical Records of Earthquake Ground Effects for Seismic Hazard Assessment. Geological Society Special Publication, 316, pp. 31-54. http://dx.doi.org/10.1144/SP316.3.

Sari, E., Çağatay, M.N., 2006. Turbidites and their association with past earthquakes in the deep Cinarcik Basin of the Marmara Sea. Geo-Marine Letters 26, 69-76.

Seeber, L, Cormier, M.-H., McHugh, C. Emre, Ö. Polonia, A, Sorlien, C. 2006. Rapid subsidence and sedimentation from oblique slip near a bend on the North Anatolian transform fault in the Marmara Sea, Turkey. Geology 34, 933-936.

Siani, G., Paterne, M., Arnold, M., Bard, E., Metivier, B., Tisnerat, N., Bassinot, F., 2000. Radiocarbon reservoir ages in the Mediterranean Sea and Black Sea. Radiocarbon 42 , 271-280.

Sorlien, C.C., Akhun, S.D., Seeber, L., Steckler, M., Shillington, D., Kurt, H., Çifçi, G., Poyraz, D. T. Gürçay, S., Dondurur, D. İmren, C. Perincek, E, Kucuk, M., Diebold, J.B, 2012. Uniform basin growth from a low-stand deltas seismic stratigraphic model, North Anatolian Fault system, Marmara Sea, Turkey. Tectonophysics. http://dx.doi.org/10.1016/j. tecto.2011.10.006

Stanev, E.V., Buesseler, K.O., Staneva, J.V., Livingston, H.D., 1995. The application of radiotracers to a study of Black Sea circulation: validation of numerical simulations against observed weapons testing and Chernobyl ${ }^{137} \mathrm{Cs}$ data. Journal of Geophysical Research 104, C5.

Stein, R.S., Barka, A.A., Dieterich, J.H., 1997. Progressive failure of the North Anatolia Fault since 1939 by earthquake stress triggering. Geophysical Journal International 128, 594-604.

St-Onge, G., Chapron, E., Mulsow, S., Salas, M., Viel, M., Debret, M., Foucher, A., Mulder, Th., Winiarski, Th., Desmet, M., Costa, P.J.M., Ghaleb, B., Jaouen, A., Locat, J., 2012. Comparison of earthquake-triggered turbidites from the Saguenay (Eastern Canada) and Reloncavi (Chilean margin) Fjords: implications for paleoseismicity and sedimentology. Sedimentary Geology 243-244, 9-107.

Straub, C., Kahle, H.-G., Schindler, C., 1997. GPS and geologic estimates of the tectonic activity in the Marmara Sea region, NW Anatolia. Journal of Geophysical Research 102, 587-601.

Stuvier, M., Reimer, P.J., Reimer, R., 2005. CALIB radiocarbon calibration 6.0. http://radiocarbon.pa.qub.ac.uk

Taylor, F.W., Mann, P., Briggs, R.W., Prentice, C.S., Jean, P., Shen, C.-C., Chiang, H.W., Jiang, X.-Y., 2011. Late Holocene paleo-uplift events at the Tapion restraining bend in Haiti: implications for earthquake recurrence in the vicinity of the 2010 rupture zone. Fall meeting AGU, San Francisco CA.

Thunell, R., Tappa, E., Varela, R., Llano, M., Astor, Y., Muller-Karger, F., Bohrer, R., 1999. Increased marine sediment suspension and fluxes following an earthquake. Nature 398, 233-236.

Toksöz, M.N., Shakal, A.F., Michael, A.J., 1979. Space-time migration of earthquakes along the North Anatolian fault zone and seismicity gaps. Pure and Applied Geophysics 117, $1258-1270$

Toksöz, M.N., Reilinger, R.E., Doll, C.G., Barka, A.A., Yalcin, N., 1999. Izmit (Turkey) earthquake of 17 August 1999: first report. Seismological Research Letters 70, 669-679.

Uçarkus, G., Cakir, Z., Armijo, E., 2011. Western termination of the Mw 7.41999 Izmit earthquake rupture: implications for the expected large earthquake in the Sea of Marmara. Turkish Journal of Earth Sciences. http://dx doi.org/10.3906/yer-0911-72.

Wells, D.L., Coppersmith, K.J., 1994. New empirical relationships among magnitude, rupture length, rupture width, rupture area, and surface displacement. Bulletin of the Seismological Society of America 84, 974-1002. 